University of Rhode Island

DigitalCommons@URI

Open Access Master's Theses

1984

\title{
An Empirical Investigation of the Concept of Transference
}

Cornelia E. Franek

University of Rhode Island

Follow this and additional works at: https://digitalcommons.uri.edu/theses

\section{Recommended Citation}

Franek, Cornelia E., "An Empirical Investigation of the Concept of Transference" (1984). Open Access Master's Theses. Paper 1549.

https://digitalcommons.uri.edu/theses/1549

This Thesis is brought to you for free and open access by DigitalCommons@URI. It has been accepted for inclusion in Open Access Master's Theses by an authorized administrator of DigitalCommons@URI. For more information, please contact digitalcommons-group@uri.edu. 
AN EMPIRICAL INVESTIGATION

OF THE CONCEPT OF TRANSFERENCE

EY

CORNELIA E. FRANEK

A THESIS SUEMITTED IN PARTIAL FULFILLMENT OF THE REQUIREMENTS FOR THE DEGREE DF

MASTER OF ARTS

IN

PSYCHOLOGY

UNIVERSITY OF RHODE ISLAND

1984 


\section{AESTRACT}

While extersive atterition has been paid to the theoretical parameters of the coricept of trarisfererice, there has beer little experimental investigation of this psychoanalytic coricept. The preserit study is ar attempt to investigate trarsfererice ir ar empirical arid rimative fashion and to develop a mears of measuremert which may provide the basis for exterisive further expiaration of this ceritral psychotherapeutic coricept.

Ir this study, measuremerit and aperatioralization of transference phenomeria is unidertaken through the combiried innovative use of two isomomphic interpersorial iriventories, the Interpersorial Behavior Iriveritary (Lomr ard MoNair, 1967 ) arid the Impact Message Iriventory (Kiesler et al, 1976) by which early chilohodd perceptiars af paremtal figures ard perceptions of a stimulus therapist (ir) this case, or videotape) can be compared.

The hypotheses addressed by this experimerit are summarized as fallows: 1) There is variability ir subjects" perceptioris of the interpersonal and interactianal style of a stimulus therapist; 2 ) This variability is related to the perceived interpersonal style of one of the subject's parents when the subject was between the ages of arid 7 ; and, 3) Individuals with parents perceived as havirig had 
"extreme". interpersonal styles during the subject's eariy childhood have more "extreme" interpersoral perceptiors of a present stimulus therapist.

Results of tests of the above hypotheses reveaied that there was variability ir individuals' perceptigrs cif a constant stimulus therapist on videotape ard that these perceptions could in fact be seen as related to perceptiors of parental iriterpersonal benavior. While caribrical correlation analyses seened to mask this relatioriship, wher, ari ipsative method of profile comrelatian (AVA prafile arialysis) was used, it was fourd that there was a high degree of correlation between the perceived interpersorial profiles of ore of the subjects" parents and the perceived interpersonal profile of the stimulus therapist. These results suggest that transferenice phemomeria may be most appropriately measured usirg ipsative approaches arid calls for further exploration of such techriques. Firally, this study also fourid that individuals who perceived ore af their parents as having had ar "extreme" iriterpersiral style (particularly ir the areas of hostility arid dominaricel also perceived the stimulus therapist as more interpersonaliy "extreme". 


\section{ACKNOWLEDGEMENT}

I would like to take the opporturity to thank my committee, Lawrerice Grebstein, Ph. D., Paul Florir, Ph.D., and Joel Cohen, Ph.D., for havirig faith in me... everi as time marched on. I couldr't have dore this without yiur trust.

Tharks also, as always, to my family for their support arid love. 


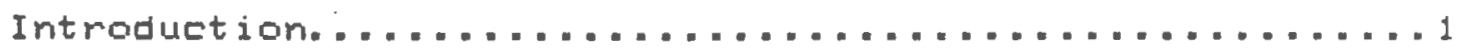

Theoretical Backgrourid of the Coricept of

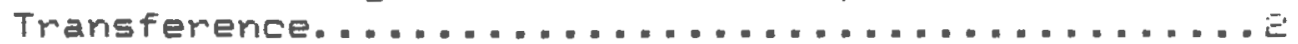

Assessment of Transference........................

Interpersonal Approaches to Transfererice.......... 14

The Impact Message Iriveritory.................. 1E

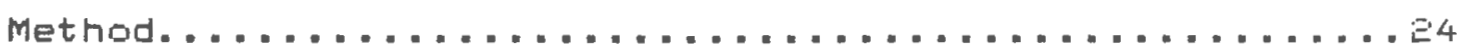

subjects...................................

Iristruments.............................

The Interpersaral Behaviar Iriventory........

The Impact Message Irveritory............. E7

Family Compasitior Questiorraire........... 31

Procedure......................................

Results.........................................

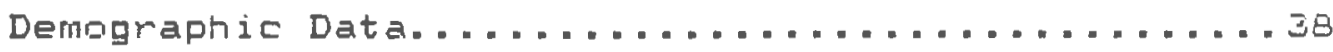

Results of the Interpersonal Behavigr Iriveritories.. 4 R

Results of the Impact Message Iriveritory.......... 44

Aralysis of Individual Response Profiles.........5b

Results of the Caronical Correlatibr Aralysis..... 5E

Results of the MANOVA Comparing Extreme and

Non-extreme Groups...................... 55

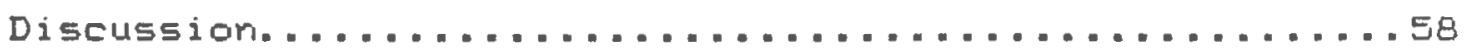




\section{Appendixes}

A. Research Conserit Form....................... TE

B. Interpersonal Behavior Iriveritary (father

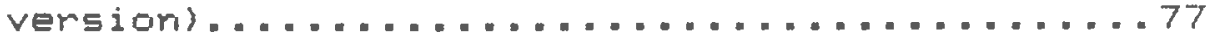

C. Impact Message Iriveritary.......... . . . . . . . . . 84

D. Family Compositior Questicrnaire.............88

E. Summary Defiritions of the 15 Initerpersorial

Categaries of the Impact Message Iriveritary

arid the Iriterpersorial Eehavicir Iriveritiry.....89

F. Individual IMI arid IEI Profile Codes ard

Correlaticri Coefficierts................

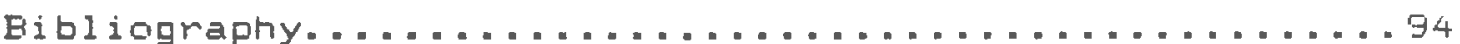




\section{LIST OF TABLES}

1. IBI Cluster Score Means arid Standard Deviations.... 4

2. IBI Cluster Score Mearis and Staridard Deviatioris by Respondent Sex..........................41

3. IBI Cluster Scome Mearis arid Staridard Deviatioris by Family Composition status................. 4 E

4. Average Response Ranges for IBI Cluster Scores.....43

5. Average Response Rariges for IEI Cluster Scores by Resporiderit Sex and Family Compositian Status.... . 44

E. IMI CIuster Score Means arid Staridard Deviatians....45

7. IMI Cluster Score Means arid Staridard Deviations

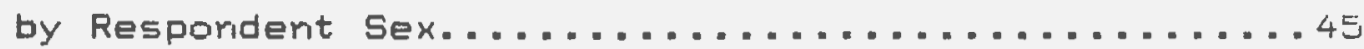

8. Average Response Ranges far IMI Cluster Scares by Respondent Sex........................4t

9. IMI Cluster Score Frequericies................4

10. IMI Cluster Score Means arid Staridard Deviatioris by Family Compasition Status.................. 49

11. Average Response Rarges for IMI Cluster Scores by Family Composition Status.....................

12. Correlation Matrix of IMI and IEI Cluster Scores... .5

13. Summary of Canonical Comrelatior Analysis of IMI

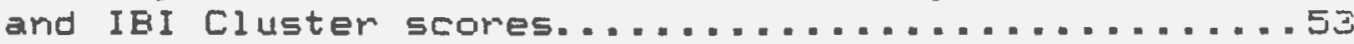

14. Structure Vectors obtained from Canorical Cormelation Analysis of IMI and IBI Cluster Scores......54

15. Summary of Redundancy Analysis between IMI and

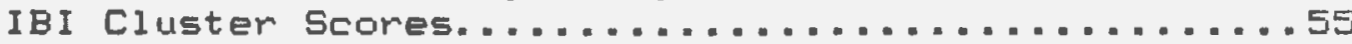

16. Summary Statistics for Univariate ANOVAs. ........57 


\section{INTRODUCTION}

The concept of transference has been central to the development of the clinical practice of psychotherapy and to the theoretical understanding of psychopathology and its treatment. However, its empirical exploration has been negligible. Dperationalization of the concept has been langely unsuccessful with the few existing attempts failing to adequately address both the perceptual and experieritial nature of the phenomenon. Furthermore, a wider understanding of transference has remained hampered by ari exclusively descriptive, idiographic, single case clincial approach. The present study is a unique attempt to begin to look at trarsfererice in an empirical and nomative fashion and to develop a means of measurement which may provide the basis for exterisive further investigation of this central psychotherapeutic concept.

A method for measuring aspects of the psychoanalytic concept of transference is explored involving the combined innovative use of two psychological inventories and experimental presentation of a videotaped therapist. Variability in perceptions of a particular therapist and the potential systematic relation of such variability to perceptions of interpersonal characteristics of individuals' parents as they are remembered from early 
childhood will be investigated.

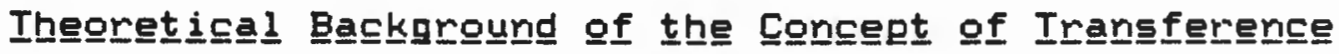

There has been uncommonly wide usage of the term 'trarsference' in the clinical literature, with meanings ranging from simply an attitude towards other persons, to feelings about a therapist, and to, more specifically, unrealistic attitudes toward a therapist (Menninger, 1958). In fact, within the general psychiatric and psychological parlance, 'transference' has often come to be used as a loose designation for all aspects of the patient's feelirigs and behavior toward the therapist.

Transference was initially referred to by Freud, who in the process of developing the tectiniques of psychoanalysis, became more and more aware of the depth and complications of the relationship between physician and patient as it developed in psychoanalytic treatment. In his first systematic statement of transference (Dora: An Analysis of a Case of Hysteria, 1905), he wrote:

"What are transferences? They are new additions or facsimilies of the impulses and phantasies that are aroused and made conscious during the progress of analysis; but they have this peculiarity, which is characteristic for their species, that they replace an earlier person by the person of the physician. To put it another way a whole series of psychological experiences are revived, not as belonging to the past, but as applying to the person of the physician at the present moment" (Freud, 1905, P. 138). 
Transferences were thus understood to constitute a special class of mental structures, derived from the past and experienced in the present with the analyst. They were not created by the psychoanalytic situation, but merely thus brought to 1 ight.

While experienced as real and contemporaneous by the patient, Freud noted that, in the eyes of the analyst transference feelings must be understood to be ari "illusion" in the sense that they are in fact the unconscious expression of feelings and wishes of the past. Freud, however, also discovered that while beirg extremely complicated and volitile, since they involve the relationship between the patient and analyst so directly, the transferences provided a urique way of understanding the patient and could become a central tool for psychoanalytic treatment.

"transfererice, which seems ordained to be the greatest obstacle to psychoanalysis becomes its most powerful ally, if its presence can be detected each time and explained to the patient" (Freud, 1905, p. 139).

The transference neurosis, the systematic crystallization of transference feelings towards the analyst, and its working through soon came to be seen by Freud as the path for resolution of psychopathology. As Langs (1976, P. 27 ) so eloquently summarizes:

"Our main heritage from Freud lies in his remarkable discovery that many reactions within a patient toward his analyst have roots in the past history 
and relationships of that patient and that the psychoanalytic resolution fo this area is the main vehicle of the intrapsychic resolutions of the patient's emotional illness, as well as the greatest dariger to this outcome".

Freud used the term transference in varied contexts over the years and at different times used the term to refer to different aspects of a patient's relationship to the analyst. This wide usage by freud has led to considerable confusion and discord anoung subsequent psychoanalytic theoreticians about the definitional boundaries of the concept. The controversy has centered primarily around the issue of whether transference refers solely to the 'distorted' aspects of the aralytic relationship or whether it also includes the more adaptive and 'reality-oriented' aspects of the relationship, and whether transference should be understaod as exclusively a phenomenon occuring in the psychoanalytic situation or cari be more widely understood as a part of all humari relationships. In fact, all of these options or facets of the concept are addressed by Freud through the developmerit of his theory and have served as catalyst for continuing debate.

The definitional debate which emerged over the past 50 years has, as mentioned earlier, focused primarily on the separation of reality from fantasy and transference manifestations from other categories of the patient's 
responses to the analyst.

In 1937 Anna Freud defined transference as "all thase impulses experienced by the patient in his relation with the analyst which are not newly created by the objective analytic situation, but have their source in early object relations and are now merely revived under the influence of the repetition compulsion" (A. Freud, 1937). Glover (1949,1937) saw transference as the "capacity ... to repeat in the current situation... attitudes developed in early family life".

During the same period of time, however, others such as Thompson were stressing the importance of separating the transference from the nontransference, reality from faritasy (Thompson, 1938). Thompson (1938) suggested that reactions to the analyst that are irrational and cannot be collaborated by others should be distinquished from responses to the analyst that are based in reality. This trend towards distirquishing the "real relationship" between analyst and patient from the transfererice relationship continued and remained a main topic of study through the 1950 s.

Menninger in offering a fairly representative definition stated that transference is "the unrealistic roles of identities unconsciously ascribed to a therapist by a patient in the regression of the psychoanalytic treatment and the patient's reactions to this 
representation derived from earlier experience" (Merininger, 1958, P. 81). He thus, by definition, requires that transference be irrational or unrealistic, that the transference phenomenon occurs in association with the regression within the psychoanalytic treatment situation, and that its expression is derived from past experience.

Lowenstein (1969) went even a step further in making a case for separating "positive transfererice" (which Loewenstein felt was alliance between the analyst and the healthy part of the patient's egol from the transfererice proper (Loewenstein, 1969, P.586). (see also Sterber, 1934; Zetzel1, 1958, Greenson, 1965.)

In contrast, others, as did Glover, maintained a position more reminiscent of Freud's earlier works which focused on the ubiquity of the trarisfererice phenomenon. Ir "Beyond the Pleasure Principle", Freud claimed that the transfererice phenomena of neurotics also could be observed in the lives of "seemingly normal people" who, on the basis of early infantile influerice, arrange repetitioris of their fate. Silverberg (1948) further suggested that transference phenomena reflected intrapsychic disturbarice only when it is used extensively, and that there was ari adaptive, nonpathological aspect. to trarsfererice ir patients' attempts to master traumatic situations through the transference. 
Langs (1976) counters, however, that the so called non-pathological forms of transfererice are more precisely identified as non-transfererice camporierits. He states that "relatively undistorted aspects of the patierit's relationship with the analyst as derived largely from relatively conflict-free ard autoromous sectors of ega functioning" have "their own genetic heritage" separate from the transfererice proper (Larigs, 1976, p.1こE). Thus While stating that both trarisference arid rontmarisfererice pheriomera have earlier aritecederits, they should be distinquished or the basis of their level of autarumy; appropriateness and distartion.

Most recently, in his landmark work. Ihe Angaㅡyㅗㄹㅗ 모 Iransference (1982), Merton Gill has again formulated the dynamics of transference in a much wider scope. Rather thatn splitting the concept of trarisfererice between rational/irrational, conscious/uricorscious, etc., Gill is a proponent of the view that trarsference is a mare basic phenomenor that is ubiquitous in humar experierice arid rict in itself pathological.

Gill points out that Freud explicitly states that the "stereotype plate" of the persor"s way of relating iricludes an aspect which has "passed through the full pracess of psychical development", is "directed toward reality", ar,d is available to the "conscious personality" (Gill, 198E, P.10 quoting from Freud, 1912). He also poirits out that 
Freud included the conscious appropriate elemerits of the person's way of relating in his concept of transfererice (Gill, 1982, P.10). Gill, strikingly exclaims:

"Rather than finding Freud"s use of "transfer-
ence" for both the canscious and repressed
bases of the patiert"s way of relating "urjust-
ified ard confusing" (refering to Loeweristeir),
I believe it does grave violerice to Freud"s
concept of trarsference and its major role ir
the analytic process to exclude its coriscious
"unobjectionable" roots" (Gill, 1982, p.11).

In stressing the ubiqitous rature of trarisfererice pheromena, Gill proposes what may be a radical adjustmerit to classical psychaaralytic theory. He clearly incorporates the 'real' iriterpersorial dimerisior of the therapeutic interaction irito the coricept of trarifererice (a view he believes is loyal to Freud's interit) and further contends that transfererice carnot be viewed as salely a distortion of the present by the past but that it is "ar. amalygam of past and present" (Gill, 1982, p.177). This formulation is critical since it suggests that the arialyst is not merely an observer by a "participarit observer" (Sullivan's term). Transference from this view "is a resultant of the interaction betweer the patient ard the analyst... and is ubiquitously present from the begiririrg of and throughout analysis" (Gill, 1982, P.177).

It is specifically through the resolutior of the transference that Gill sees basic structural charige as 
possible. This has, of course, been part arid parcel cif the traditional psychoanalytic view. However, he gaes beycrid exclusively explaining the origin of that aspect af the transference which derives from the past, arid conterids that focusing on the "here and now" and the preserit interpersonal nature of the transfererice is ar importarit and elucidating. Thus Gill has iritegrated a more definitive interpersonal dimension with a psychoaralytic perspective.

As Wachtel (1977) very clearly explicated, psychoanalysis actually does iriclude the use af both intrapsychic and interpersonal models although it traditionally has been considered to have overemphasized the intrapsychic determinarits of behavior ir relatior ta the interpersonal determinarits. Gill's work clearly balarices this scale somewhat:

"The iridividual sees the world rict orily as his intrapsychic patterns dictate but alsi as he veridically assesses it. Furthermore, the two kinds of determinarits mutually irifluence each other" (Gill, 1982, P. Gอ).

He continues:

"The intrapsychic patterns not orly deternine selective attention to those asepcts of the external world which conform to them, but the individual behaves in such a way as to erihance the likelihood that the resporise he meets will indeed confirm the views with which he sets cul. This external validation in turn is mecessary for the maintenance of these patterns" (Gill, 1082, P. 92). 
Wachtel suggests that it is in this last step (the understanding of the maintenance of intrapsychic patterris) where psychanalytic theory postulates internal pressures without enough reference to the external world. It has, however, been the unique contribution of psychoaralysis to demonstrate the power and persistance of iritrapsychic determinants. Gill, in my view, by struggling with the interaction with the iriterpersonal world, has beeri able ta maintain this unique and powerful heritage without allowirg them to become barren ard artificial, and irfact has strengthened psychoanalytic theory. He has undertaker this feat by addressing the centrality of transfererce. It remains the most powerful tool since, as Gill farmulates

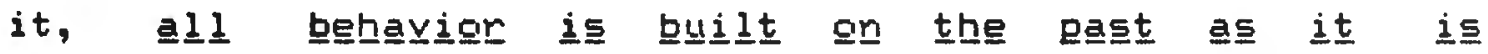

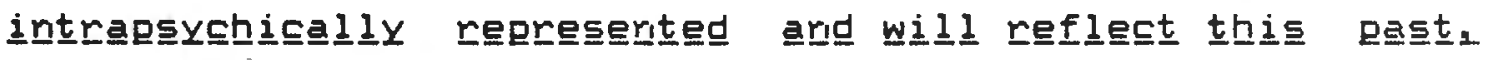

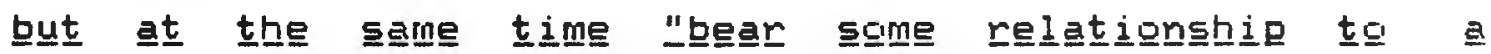

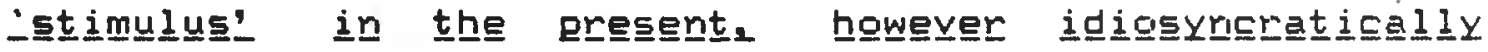

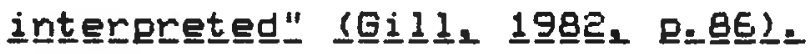

Assegsmㅡ른 of Irangeference.

Although postulated to be central to psychoanalytic oriented treatment and the vehicle for the resolution of neurosis, transference has not been very well defined for research purposes, nor are there normative measures for its assessment. Luborsky and Spence (1978) rightly point out that "quantitative research on the patient's transfererice 
response to the analyst is slight, even though cliriciars have placed transference at the core of what rieeds to change in effective psychoanlytic treatment" (Luborsky ard Spence, 1978, p. 344).

The assessment of trarisfererce has been carried out primarily in the clinical setting as part and parcel of the therapeutic endeavor. In fact in this coritext, "assessment" of the quality and nature of the transfererice is the constarit and ceritral focus of therapy/arialysis. Such assessment is, however, strictly idiographic, confiried to the single case clinical experience ard has rot been attempted in a more systematic cr normative fashior.

The tools for the assessment of transfererice withir the therapeutic situation have traditionally been (1) the analysis of free associative material whereby derivatives of the transference can be iriterpreted, arid (e) the analysis of countertrarisference feelirigs evoked by the patient in the therapist. (This is a much less traditioral and more recent inclusion in part largely due to the influence of sullivanian interpersonal theory where distinct and deliberate focus is giver to the "pulls" created by the patient and their influerice on the therapist.)

Few attempts have been made to delineate the transferential aspects of the therapeutic relatiorship ir an operationalized, scientific fashior. Chance (195こ) 
attempted to study the concept of transfererice operationally as the similarity between the patient's description of his or her "sigrificarit parent" arid his or her description of the psychotherapist. While ar admirable attempt to quantify a clinical and theoretical coricept, there are clear difficulties with Chance's appraach. The choice of descriptive similarities betweer the sigrificart parent and therapist is a rather limited and superficial aspect of transference. As has been iridicated by the previously cited literature, the critical aspects of transfererice are in the experiengege of the relatioriship arid are thus much more affective arid experiential than overtly descriptive.

Fiedler and Senior (195e) also attempted to corstruct an operational definition of trarsferene by comparing the patient's description of the ideal person arid his or her" prediction of the psychotherapist's self descriptian with similar measures filled out by the therapist. Agair difficulties with this approach are eviderit. While highlighting the projective aspect of the patient's perception and contrasting it to "reality", Fiedler and Senior's definition lost the cormection of such distartior with past experience.

Apfelbaum (1958) had patients fill out special $Q$ sort cards indicating his/her expectations of the therapist he 
or she would be assigned althoug they had not as yet beeri introduced. All of these attempts at operationalizatior had serious difficulties based both on the quarititative methods and on the differing clinical conceptiors of transference. In general, they were unable to capture the critical elements of the phenomenon by focusing or descriptive rather than on interpersonal experience.

Szasz (1963) points out arother difficulty that thase investigating transfererice ran up agairist; ramely, that transference, similar to delusion or fantasy, is defired through a contrast with reality. Transfererice arid reality are thus largely an outsider's judgement of the patient's behavior. In struggling with this problem, Szasz came to the conclusion that transference "is essentialiy a universal aspect of object relatedness" arid further distinquished transference from trarisference rieurasis by characterizing transference neurosis by a more exterisive and coherent set of transferences. It seems, however, that Szasz, as well, gets caught in the trap of having to abandon ship in terms of operationalization since absolute objective reality cannot be separated from individual experience. What is needed in an approach which integrates and embraces the subjectivity of human experience and explores its parameters.

Other studies have explored the measurement of transference in the actual clincial context, studying 
recordings of psychoanalytic sessions, rating the amourits of transference material, etc., but not addressirig the experimental validation or normative issues (Luborsky et al, 1973; Luborsky et al, 1975; Graff and Luborsky, 1977).

A goal of this study is to have operationally defiried transference in a way that is more loyal to the clirical pheriomenon of transference so that (1) the pheriomerion can begin to be experimentally validated, and (Z) a method car be developed which will allow for further inversigation of the phenomenon of transference which has been hampered by exclusively iodiographic, single case, clirical descriptiors of the psychoanalytic literature. It is in fact astonishing how little is known about the parameters of transference pheriomena, its development, resolutior, arid varying expressions.

\section{Integreersona l Apgroacheses.}

Interpersonal theomies, while coming from a different theoretical orientation, provide the most closely allied approach to an understanding of the therapeutic irteractior and of the concept of transference. The concept of repetition of iriterpersonal patterns is a central and paramount tenant of Sullivarian interpersonal theory. Sullivan, in fact, summarized the essence of human life as: 
"the relatively enduring pattern of recurrent interpersorial situaltions" (Sullivan, 1953, pP. 110-111) and saw the individual, his perceptions, and his impacts on others as the driving force of these recurrences.

Thus, as in psychoanalytic theory, the importance of the act of perception, or rather perceiving, becames central to interpersonal theory. The process of pereiving is integrally entwined in all interactions and in the very creation of a personal reality as well as in the creation of others responses to us. The central, far-reaching systemic consequerices are clear. The importarice of the individual act of perceiving is inherent in the interpersonal approach as it is seen as "the interpolatiar of whatever... outside reality is and what we have in our minds" (Sullivan, 1953, p.28). Sullivan in fact clearly states "what we have in our minds begins in experierce" (Sullivar, 1953, P. 28), and furthermore that distorted perception of current situations is a result of the intrusion and revival or experience with sigrificant.people in the past. He called this phenomenon "parataxic distortion", and saw "parataxic concomitants" as "permanent complicating factors in the patient's perceptiors of Eignificant other people" (Sullivan, 1940, p. 235).

"The integration of a situatior is parataxic when... besides the interpersonal situation as defined within the awareness of the speaker, there is a concomitant interpersonal situatior, quite different as to its principal in- 
tegrating tendencies, of which the speaker is more or less completely unaware" (Sullivar, 1940, P. 42).

As Kiesler (1982) points out: within the therapeutic context, a parataxic distortion would "take the form of generalizing to the therapist as a preserit-day partrier earlier experiences in interpersonal relatedness" (Kiesler, 1982, P.4). Thus the whole interpersorial caricept of parataxic distortion, although differing in its formulation to some extent, can clearly be seen as referririg to the phenomenon in the psychoanalytic literature described as transference. It is in this deeply interpersonal aspect of the therapeutic relationship that the psychoanalytic arid interpersonal tranditions come closest.

There have been attempts by interpersanal theorists ta assess and measure these interpersonal cancepts. The Impact Message Inventory (Kiesler et al, 197E) is ore of these attempts which is specifically geared toward assessment of the therapeutic relationship.

Ine Imeact Mes

The Impact Message Inventory (IMI) (Kiesler et al, 1976) is an inveritory "designed to assess relationship behaviors in dyads"..."tapping momentary affective, cognitive, and behavioral covert erigagements of ore persori by another during ongoing face-to-face communication" (Kiesler, 1979, P. 363). The IMI is unique in offeririg a 
standardized inventory for assessing coverert affective and cognitive reactions to another, and as such "provides a valuable source of clinical information that could not be derived from previous assessment devices" (Wiggirs, 198E', P. 200 ).

As a basis for developing the IMI, Kiesler (1982) states that "a major set of cues for identifying the recurrent interpersonal climate a persor praduces are the distinct covert ard overt resparses the person elicits or "pulls" from others" (Kiesler, 198E, p.7). He believes that the best clues to a person's private carceptioris of self are those covert engagements produced in others. This comcept is deeply rooted in iriterpersorial sacial interactionist theory with its basic assumptions that "relationship is inevitable" ard pervasive ir humar transaction, and its emphasis on "self preseritatiors" ard the resulting evoked reciproval responses (Kiesler, 1979). While the focus of the IMI is or assessing the "pulls" evoked by one individual in another (the impact message), its design apppears to have promise for assessirg characteristic affective, cognitive, arid behaviaral gercegetigns of one iridividual of another as well.

The IMI asks questions grouped in three subclasses (direct feelings, action tendencies, and perceived evokirig messages) under the general headings of (1) When I am with 
this person he makes me feel... (direct feelings); (Z) Wher I am with this person he makes me feel that... (actiar tendencies): (3) When I am with this person it appears ta me that... (perceived evokirig messages). Withir each cif these sections the respondent is required to rate his responses to ar interaction with a target persor. Ir the framework desigried by Kiesler, this irformation is used ta characterize the "evokirig" style arid messages cif the tarrget person. The conterition of this study is that the IMI resegendent's perceptior arid iriterpretatiori of the interaction is as important a variable arid that it may infact be specifically reflective of transf झremce phericieria. The IMI is based or the assumptiar that "(1) the therapist becomes perceived as a significarit other, arid (E) the cliert will commuricate to the therapist in the same duplicitous, self-defeatirig way that he/she commuricates with other importart people ir his life (i.e., that he will serid the same rigid ard extreme evoking messages to the therapist he serids to others)" (Kiesler, 198E, P.15). TiZ this should be added: ard eercẹive this sigrificart other and his iriteraction in the same "rigid ard extreme" way he has others. These assumptions are, of course, rotably similar to the assumptiors underlyirg the psychoaralytic notion of trarisference.

To again quickly summarize how the IMI is used in less techrical terms: Two individuals partake ir ari iriteracticir 
(for instance, therapist and client). After the interaction the IMI is filled out by one of the persors about the iriteraction with the other. (When I am with this persons, he makes me feel..., etc.). The resporises to these questions ane then aralyzed and scared to deternine the evaking style of the cther persor. In other wards, the responses to the IMI by are persor are used to characterize the ather persari, nget the persari wha filled aut the IMI.

This study suggests that the persor filling out the IMI (the resporiderit) in revealing how he/she feels, thiriks about, arid perceives the iriteractior is givirig us vital irformation about him/herself (as well as abaut the ather). I believe he/she is givirg us irformation about their gwr iriterral experience iri relaticiships .... trarisfererice. Furthermore, the assumptiars that resporiderits are biasfree, uricoritamirated instrumerits in their ability to mirrar back the qualities of the other persor, without corsiderirg these perceptual biases seems rather simplistic.

Most of the studies dore with the IMI up uritil this time have focused primarily or the "evakirig style" af ari interactarit. Several authors have studied the iriterpersonal styles of obsessives arid hysterics (Arichir, 1978; Kiesler ard Federmar, 1978; Chirico, 1977; Chirico, Kiesler, Carror and Baker, 1980). Other studies have focused or daminarit vs. submissive interpersorial styles 
(Schwaniger-Morse, 1979), differences in iriterpersarial impacts as a functian of locus of cortrol orieriation (Thibodeau, 1978), corversational and social resporises to depressive interpersonal behavior (Howes, 1979), arid or the effectiveress of assertiveness training or the basis of its evoking respones (Reagan and Kallmar, 1978; Reagan, 1979).

A few studies have attempted to look at "decodirg differemces". Chimico (1977), Chirico et al (1980) arid Chirice (1380) studied differing decodirg styles of obsessive and hysteric persoralities. Chirica (19en) aptly pointed out that uritil very receritly the differences amorg the decaders ar the receivers of messages have beeri neglected in the research of the communication process. The broad coriclusior of these three studies was that persorality styles differ ir decodirg capabilities arid further that the decoding of iriterpersoral relatiarships may reveal differential charriel-input "domirarice".

$$
\text { Kyle (1976) used the IMI to study persoral perceptiori }
$$

after a brief interaction as a furction of $\mathrm{Hi}$ vs. Low Inclusior scores. His study is also urique in his attention to both the ericoding arid decodirig of ari interactior...: "it is rot the ericoder or the decoder" alone, but the iriteraction between them, that creates the impact arid the basis for judgemerits" (Kyle, 1976, p.71). He coricluded that "the measured impacts are systematically related to the personalities of the interactarit (ir this 
case $\mathrm{Hi}$ vs. Low Inclusion scores), such that both ericaders and decoders contribute to the impact experiericed by each" (Kyle, 1976, p.71).

While these studies make ar attempt to look at the "decoding" of the impact message, they do so exclusively as a secoridary process, thus ofteri failing to isolate the specific variables assaciated with decodirg differerices. This study hypothesizes that transfererice pheromeria are a major variable in the perception of ariother within a dyadic iriteractior.

The IMI car be a particularly serisitive togl for evoking those aspects of the dyadic interaction which may be thought of as transfererice if it is used to assess the decgodirg of the iriteraction by the respgriderit as opposed ta

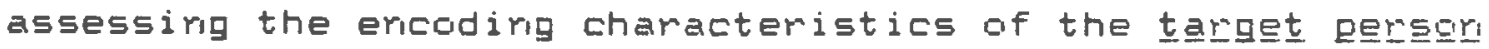
by the respariderit's responses to the interaction. Ir usirg the IMI in this way, the inquiry becomes iridirect sra projective, which is ar importarit comparient for the measuremerit of transference phenomeria. Rather that asking abiut the resporident"s feelings arid thoughts directly, the IMI format asks for an assessmerit of another's effect. I suggest the use of this assessmerit to characterize the resegondent and his/her perceptions.

The indirect and projective quality of the inquiry with respect to. the actual focus of the data seems 
particularly apt since trarisfererice pheromeria are characteristically described as being defended against (ar infact uncorscious) and thus most easily exposed by projective and indirect techniques. Gill in fact clains that both the patient and analyst resist the implications of the trarisfererice and thus that it usually remains concealed. (He suggests that it is most ofter brought to light by allusion (Gill, 1982, P.178).)

The other critical aspect of trarisfererice that rieeds to be addressed is, of course, the correlation betweer preserit experierice ard perceptior of ari iriteractior, arid earlier experierice with sigrificart others. The IMI again offers a unique opportunity for exploririg this pheriomerior. The irveritory was designed to be isomorphic with ard structured or the Iriterpersciral Behavior Irivertary by Larn and McNair (1967). The Interpersorial Eehavior Iriveritary (Lorr ard MeNair, 1967) was developed as a tool far assessing interpersonal behavior styles arid classifyirig them. It outlines 15 dimerision of interpersorial behaviar in a circumplex ordering: 1)domirant, Elcompetitive, 3) hostile, 4)mistrusting, 5)detached, 6) inhibited, 7) submissive, 8) succorant, 9)abasive, 1(b) defererit, 11) agreeable, 12) nurturant, 13) affiliative, 14) sociable, 15)exhibitionistic. The IMI classifies its results alcrg these very same interpersoral dimerisions. The parallel structure of the IMI and the IBI thus offer an opporturity 
to assess the correlation of the iriterpersorial style of significant others in the past (as the subject saw, them) and the present perceptions of a therapist which is si widely refermed to in the clinical psychiatric ard psychological literature.

In the present study subjects are asked to assess the interpersoral characteristics of significart others in their early lives on the Iriterpersonal Behavior Iriveritory arid ther to complete the Impact Message Invertary followirg ar experimerital situation in which they watch a vided tape of a therapist iritroducing them to psychotherapy. The hypotheses addressed are: 1) that there is variability iri subjects" perceptions of the iriterpersirial arid interactional style of the stimulus therapist as measured by their responses to the Impact Message Iriveritory; $\Xi$ ) that the variability in the perceptions of the iriteractibral and iriterpersorial style of the stimulus therapist is related ta the perceived interpersaral style of crie of the subject's parerits (wheri the subjects was between the ages of $D$ arid 7 ) as indicated by subjects" resporises to the Iriterpersciral Behavior Inveritory; ard 3) that individuals with parerits categorized as having "extreme" interpersonal styles by the subject"s resporises to the IBI have "extreme" iriterpersarial reactiors arid perceptions of a preserit stimulus (the therapist on videotape). 
METHOD

\section{트느로트드토}

Subjects were $1 \in 7$ male and female uridergraduate students students at the University of Rhode Island. There was no theoretical reason for selecting any particular mix of males and females for the subject pool of this study as transfemerice is expected to be a ubiquitous pheriomerion without sex differeritiatior.

Subjects were recruited from several iritroductary psychology courses and were encouraged to voluriteer for a study as part of their course or receive additional credit for participatior. Because of the strong encouragemerit and/or requiremerit for participation in an experimental study in the courses from which subjects were recruited, it does not appear that those baises associated with the self selection of true volunteers are of particular corcerr ir this study.

\section{Irgstruumeritg}

Three instmuments were used in this experimerit. They include: 1) the Interpersonal Behavior Inventory (IBI) Forri) 4 (Lorr and MCNair, 1967); 2) the Impact Message Inventory (IMI) Form II (Kiesler et al, 1976); and, 3) a demographic Family Composition Questionnare. These instruments are 
provided in Appendices B, C, arid D respectively.

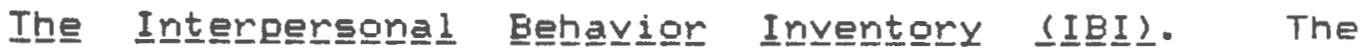
Interpersonal Behavior Inventory, Form 4 is a 140 item inventory designed to assess and categorize interpersanal behavior. The IBI postulates 15 circumplex-ordered dimensions of interpersorial behavior. The dimersions identified by Lorr ard MeNair as comprising the interpersonal circle are (in circular order): 1)domirant,
e) competitive,
3) hostile,
4) mistrusting,
5) det ached,

6) irihibited,

7) submissive,

8) succorant,

9) abasive,

10) deferent, 11) agreeable, 12) rurturant, 13) affiliative, 14) scciable, 15)exhibitionistic. Defiritions of each of these categories are included in Apperidix E.

The IBI has beer used primarily by merital health professionals to categorize the iriterpersonal behavior of patients, initially having been desigred to expand on the work of Leary and others on interpersonal systems of personality diagnosis. The IBI has undergane considerable revision through the years culminating in the IBI - Form 4 (see Lorr ard MCNair, 1963; Lorr arid MCNair, 1965; Lorr and MoNair, 1966)> It has developed irito "a useful clinical device for assessment of patient characteristics... both or substantive and psychometric grounds" (Wiggins, 1982, P. 192).

Although developed from professional ratings of patient samples,. similar psychometric structure was 
obtained when college students were asked to rate acquaintances (Lorr and McNair, 1965). The use of untrained raters was thus shown to be possible as was the assessment of normal as well as neurotic populatioris. eNorms for both psychiatric and rormal populatiors are provided for the IBI.) In this experimerit, subjects completed the IBI twice, rating each of their parents" interpersonal actions.

Each item of the IBI provides a statemerit ta be endorsed on a four point scale (1-riot at all, $2-$ occasionally, 3-fairly often, 4-quite ofteril. Scores for each interpersonal dimension are obtairied using a key provided by Lorr and McNair. These scores are then collapsed into four "cluster" scores of four iriterpersorial types ideritified by Lorr arid MaNair (1965).

$$
\begin{aligned}
& \text { Type I : irhibited - abasive - submissive } \\
& \text { Type II : agreeable - nurturant - sociable } \\
& \text { Type III : hostile - mistrustful - detached } \\
& \text { Type IV : competitive - dominant - exhibitionistic }
\end{aligned}
$$

These faur interpersonal types have been showr to rot orily be distinct and meaningful categories theoretically (Wiggins, 1982) but have been shown to be consistent and reliable isomorphic structures between the two instrument used in this study (the Interpersonal Behavior Inveritory and the Impact Message Inventory) (Kiesler, persorial 
communication). Studies have also shown that these foum interpersonal clusters meliably classify psychiatric groups (Lorr, Bishop, McNair, 1966; MCNair and Lorr, 1965).

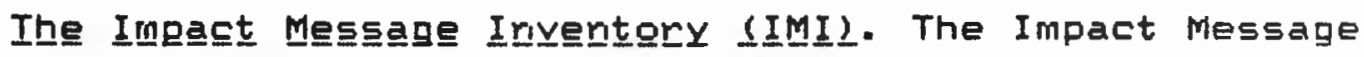
Inventory (Kiesler et al, 1976) is a 90 item inventary "designed to assess relationship behaviors in dyads, including counselor/client"... "tapping momentary affective, cognitive, and behavioral covert erigagement of ore persori to another during ongoing face-to-face commurication" (Kiesler, 1979, p. 363). Ir offering a standardized inventory for assessing covert affective ard cognitive reactions it "provides a valuable source of clirical information that could not be derived from previous assessment devices" (Wiggins, 1982, P. 200).

The IMI was designed to take the categaries of iriterpersonal behavior outlined by Lorr and McNair arid ta build an instrument measuring subjective reactions elicited by such interpersonal behaviors. The IMI was thus desigried to be statistically isomorphic to the IBI. Exterisive itern analyses were conducted to produce 6 items for each of the Lomp and MCNair 15 interpersonal scales and to provide item sets that woul yield a circular ordering in two dimensional space parallel to the IBI.

The IMI asks questions grouped in three subclasses ldirect feelings, action tendencies, and perceived evoking messages) under the general headings of (1) When I am with 
this person he makes me feel... (direct feelings); (E) When I am with this person he makes me feel that... (action tendencies); (3) When I am with this person it appaers to me that... (perceived evoling messages). Within each of these sections the responderit is required to rate his response to an interaction with a target persar. Responses are rated on a four point scale (1-not at all, e-somewhat, 3-moderately so, 4-very much sol.

As previously mentioned, the IMI (as does the IBI) produces scares for the 15 circumplex interperstrial dimensioris established by Lorr ard McNair. High levels of internal consistency reliability were obtained far the IMI subscales with coefficients rarging from. 80 to. 99. Ir a tnatrix of $Q$ coefficierits orly 10 of the $8 E$ values were below. 80 , and only 4 below. 70, with the lowest beirg. 57 . Perkins et al's (1979) data further provided support for the predicted circumplex ordering of the 15 iriterpersarial categories, but suggested that 3 factors are involved.

The IMI data can also be analyzed in terms of four "cluster" scores (as the IBI). Kiesler (1984) indicates that the cluster cores provide "ar economical respresentation of the variance present amoung the 15 scales and indices of the 2 axes, coritrol ard affiliation, that underpin the interpersonal circle". They also address a criticism by wiggins (1982) that a lack of 
distinctiveness exists among several of the 15 scales and thus "that a number of them could be combined irito more meliable and distirictive measures" (Wiggins, 198Z, p. EQ(2). The cluster scores possess very high degrees of iriterrial consistericy reliability (with alphas ranging from. 839 to .890) relative to a single scale score (Kiesler et al, 1982). As mentioried earlier the IMI cluster scores were also found to be corisistent with the IBI clusters derived by Lorr and MCNair (1966) and were thus used in this study. The cluster scores are calculated accordirig the following formula:

$$
\begin{aligned}
& \text { Dominant }=\text { Exhibitionistic + Dominart + Competitive } / \Xi \\
& \text { Hostile= Hostile + Mistrustirg + Detached/J } \\
& \text { Submissive= Abasive + Submissive + Succorart/3 } \\
& \text { Friendly= Agreeable + Nurturarit + Affiliative/J }
\end{aligned}
$$

Norrns for the IMI are still incomplete in part because the trarisactional nature of the iristrumerit leads to great variation in the way the instrumerit has beer used. Resporidents as welㅣ 므 target persors have varied greatly ifrom experimental confederates, to sigrificart others, to videctaped interactants, etc.). The rorms for the standardization of the instrument were based on resporises to stylistically pure written descriptions and are thus actually probably indictors of "ceiling values" rather thar usable norms for other studies (Kiesler, 1984). Kiesler (1984) in his soon to be published research manual for the 
IMI does, however, provide a listing of mear scores for various smaple groups reported in IMI studies to date. Most studies report mean scale scores for groups rargirg from 1.22 to 2.64 labout a 1.4 range or a 4 porit item scale) and cluster means between 1.26 and E.58. Kiesler also notes that lower rarige meari scores were obtairied ir studies where resporidents were strangers to Actors, which is the case in this study.

Similarly, reliability figures for the IMI have beer difficult to obtain. Only $E$ of the 40 available IMI studies knowr by kiesler repart reliability iriformation (Kiesler, 1984). In fact the corveritiarial measuremerit of reliability has proven to be problematic because of the transactional rature of the iristrument, where both acter arid resporderit, arid their particular interactive fit all cartribute to the "true" variance of the resulting scores. It would thus be conceptually false to corisider variarice attributable to IMI responderits as exclusively "ernom" variance. In fact, it the very purpase of this study to have addressed this variarice arid to have hypothesized a systematic basis to it. As a result of the problematic nature of reliability measurement for the IMI, Kiesler (1984) suggests that generalizability arialysis along the Iines suggested by Crombach, Glese, Nanda, and Rajaratriam (1972) is an appropriate alternative to be pursued. 


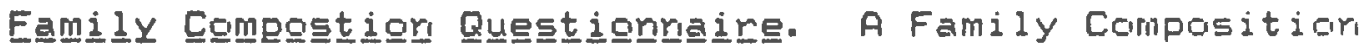
Questionnaire designed for this study, was used to determine the demographic compositior of the fanilies af subjects during the subjects" childhagd sage birth to seven) and to indicate the ideritity of the individuels indentified as "parent" in the completion of the Interpersorial Eehavior Iriventary. The Fanily Composition. Questionnaire was attached to the two IBIs completed by the subject.

\section{Pro돌ㅁ브를}

Voluriteers were recruited from several iritroductony uridergraduate psycholagy couses by preseritiris a shert description of the most gerieral focus of the experimerit and requiremerits for participatior to the classes. The experiment was described as beirg coricerred with the riatile of therapist/clierit relatiorships, particularly the explorations of how to match therapists ard clierits. It was further stated that the investigator was interested ir some background information about their experierice ir their families and then was also iriterested in their feedback about how a particular therapist "came across to them".

The only requiremerit for participatior was availability for two periods of time with at least a weets spacing in between the two times. The first admiristration required approximately $45-60$ mirutes ard the secord, $20-30$ 
minutes. No financial remumeration for participatior was involved. However, participatian abtained credit towards course requirements. Patential participarits were assured that all information giver during their involvemert in the experiment would be kept aronymous arid iri absalute confidence.

At the first meetirg each participarit was asked ta complete an Informed Consent Form (Apperidix A) ard ther ta complete a Family Composition Questionraime (Apperdix D) clearly specifyirg the composition of their family which the subject was betweer the ages af o arid 7 . The questionnaire also iridicated the ideritity arid preserice af sigrificarit others who may have been influeritial caregivers in lieu of parerits. Or this questiormaire, as well as ather, subjects were asked to use a four digit code desigriated by themselves to ideritify their forms ard by which anorymity ard confideritiality were mairitaired. There was no need for personal ideritification af ary af the forms, but there was a need to krow which forms had beer filled out by the same individual. The four digit cade was used for the purpose of matching the various iristrumerits completed by the same individual.

After completing the Fanily Composition Questigrmaire, subjects were asked to fill out the Interpersonal Behavior Iriventory - Form. 4 (Lorr and MCNair, 19E7). Subjects 
filled out the IBI about each of their parerits. (Each IBI requires approximately 25 minutes to complete.) "Parerits" referred to those individuals who were in parerital caregiving roles for the subject between the ages of 0 arid 7. They thus need not be biological parerits. If more that ore "father" or "mother" is ideritified by the subject during those years ffor instarice as a result of divorce arid remarriagel the subject will be asked to fill out the IEI for that individual who lived with the subject durirg those years.

The secorid phase of the experimerit was commericed cire week after the completior of the IBIS. This periad af time was been set aside to avaid ary reactivity betweer the responses to the IBI and IMI ard was plarired to coiricide with school vacation. Following the ore weet, period, the subjects were asked to view a short videotape iritroducirg them to psychotherapy. The videstape was specifically designed to remain quite neutral arid not to "pull" for definitive affective or cogritive reactiors but rather to be a vehicle for projective processes. An attempt was thus made to control for extranecius iriterpersorial interaction and to, as much as possible, pravide ar experimental "blank screen" without forfeiting the quality of an actual human interaction which would be characteristic of a therapeutic situaticr. 
The videotape was preceeded by shart introduction by the investigator iriterided to 1) focus the subject or the task, E) induce a situation or state of marid which might be comparable to that surmourdirg a therapeutic appoiritmerit, 3) heighten the subject's preparedriess arid iriterest fior the task of making judgemerits about how they might feei interactirig with the person or the videatape. This introduction was approximately as follows:

You are about to meet a therapist via videatape. I an going to be very iriterested in how you assess this person. In ather words, how he comes acriss to each of you iridividually.

So that you car begin to really imagire what it would be like to really be with this person arid to see them as someone you might have as a therapist, I would like you to take some time to thirk. about a specific problem or coricerr that you may have which you might talk to a therapist absut if you had a chance.

I'd like to take a couple mirutes befare we start for everyorie to ideritify a particular probiem that you might speak to a therapist abgut arid to sperd time thinking about that so that you are in the right "frame of mirid" to really tell me how the therapist you' re goirig to see might be to talk to, arid how he cones across to you.

(three minutes duratior)

Good, I hope you have all thought about a specific problem that you might speak to a therapist about. We" re going to watch the videstape now, arid I would like you imagine what it would be like to really be interacting with this person and how he might make you feel. 
The videotape was made using an actual male therapist who was chosen by corisensus of several psycholggists as being an individual with rather neutral appeararice (i.e. not showing any overt visual cues of particular group gr philosophical affiliation). The therapist was choser to be middle-aged (4D) and to not suggest either a sigrificarity youthful or paternalistic appearance. The chaice of a male therapist was made simply on the grounds that sex was going to be held corstarit in this experimerit, arid giver that fact and the fact that the IMI uses male promouris ard a I arge: part of the thearetical literature assumes that the treating persor is male, it was most expediarit ard consisterit to use a male. It is haped that further studies will compare the use of a female therapist.

Following the viewing of the videotape, the subjects: completed the Impact Message Iriveritary "imagining how it would be to be actualdy iriteracting with the therapist or the videotape". As mentioried earlier", the Impact Message Inventory is an instrument desigred to tap the covert affective, cogritive, and behavioral pulls of ar iridividual in an interaction in the present. In resporise to the instructions: "Imagine you are in this person"s preserice, in the process of interacting with him. Focus or the immediate reactions you would be experiericing...", outlired by the IMI, the subjects rated their reactiors in three categories: "When I am with this persors he makes me 
feel...", "When I am with this persor he makes me feel that...", "When I am with this persor it appears to me that...". The IMI-Form I I takes approximately 15 mirutes to complete.

The hypotheses addressed by this experiment car again be summarized as follows:

1) There is variability ir subjects" perceptiors of the interpersorial arid interactional style of the stimulus therapist as measured by their responses ta the Impact Message Inventory.

ᄅ) Variability in the perceptioris of the interactional and interpersonal style af the stimulus. therapist (as measured by the IMI) is related to the perceived interpersorial style of gree of the subject"s parerits (when the subject was between the ages of arid 7 ) as iridicated by subject's responses to the IEI.

3) Individuals with parents categorized as having "extreme" iriterpersorial styles by the subject's respirises to the IBI have more "extreme" interpersonal reactions arid perceptions of a present interactional stimulus as measured by the IMI. 


\section{RESULTS}

The stated hypotheses in this study were gerierally supported by the results. Hypothesis 1 - there is variability in subjects' perceptions of the interpersaral and interactioral style of the stimulus therapist as measured by their responses to the Impact Message Inventory - was clearly supported. Results of the tests of the second hypothesis provided mixed results. It was fuurid

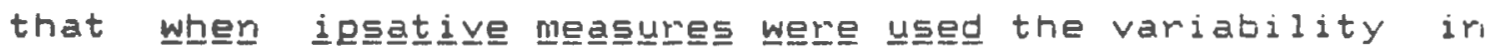
the perceptions of the interactioral arid interpersorial style of the stimulus therapist (as measured by the IMI) was related to the perceived interpersonal style of ore of the subject's parerits (wheri the subject was between the ages of 0 and 7) as indicated by subject's mesponses to the IBI. However, when measures collapsing data from the whale sample were used (canonical correlatigr), significarit results were not obtained. Hypothesis 3 - individuals with parents categorized as having "extreme" iriterpersaral styles by the subjects's responses to the IBI have mare "extreme" interpersonal reactions and perceptions of a present interactional stimulus as measured by the IMI - was supported. Subjects who gave extreme positive cluster 
ratings to one of their parerit's past behaviar (particularly on hostility and dominance) indicated more extreme responses to and perceptions of the stimulus therapist. Details of all the results are preserited below.

\section{DEMEGGRAPHIE DEIA}

The Family Composition Questionnaire administered to the subjects of this experimert provided the followirg information. The final sample of uridergraduate psychelcgy students included $34.13 \%$ males, EE. $77 \%$ females, arid $3.59 \%$ students who did not identify their sex. The age of these students ranged from 17 to 35 , with a mean of 19.8 years of age. Thirty-five percent of the subject sample was 19 years of age, arid $88 \%$ of the subject sample was el years of age or younger. The female sample was slightly youriger than the male population.

Ninety-seven percent of the subjects participating ir this study identified their biological mother as their primary mother figure during the years D-7. Ari adipted mother was identified as the primary maternal figure by 1. $8 \%$ of the subjects, and there were orily two cases (less than $2 \times)$ which identified a step-mother or other relative as the primary maternal figure during the years $0-7$.

Similarly, 95\% of the subjects identified biological fathers as their primary paternal figure during the ages of Q-7. Adopted fathers were identified as primary paterral 
figures during these years by $2.4 \%$ of the subjects, and again less than $2 \%$ identified stepfathers or other relatives as their primary paternal figures durirg the ages of $0-7$.

Niriety-eight percent of the subjects iridicated that they were with their primary maternal figure for all the years between ages $D$ and 7 . Ninety-four percerit of the subjects indicated that they were with their primary paternal figure for all the years between ages 0 arid 7. The remaining $2 \%$ and $6 \%$, respectively, were with their primary maternal or paternal figure for a variety of years between the ages of 0 and 7 .

Orily $6.6 \%$ of the subjects indicated that they had a second maternal figure betweer the ages of 0 ard 7 , ard orly 4.8x indicated having a secord paterral figure durirg those years.

Eighty-seven percerit of the subjects iridicated that the composition of their family was preserity the same as it had been wher they were between the ages of $b$ ard 7. The remainirg $13 \%$ indicated changes ranging from death af a maternal or paternal figure, to divorce, or to their awr marriage. 


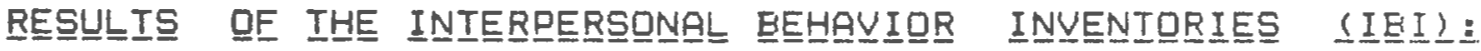
The Interpersonal Behavior Inventory (IBI) was completed by $16 \in$ subjects. One hundred sixty-five subjects completed an Interpersonal Eehavior Inveritory about their father (primary paterral figure) arid one hundred sixty-six subjects completed the Iriterpersonal Behavior Iriveritery about their mother (primary maternal figure). Results af the completed IBIs were tabulated ard corverted irita "cluster" scores. The mean scores and standard deviatigris obtained are as follows:

TABLE 1

IBI CLUSTER SCORE MEANS AND STANDARD DEVIATIONS

\begin{tabular}{lcccc} 
& \multicolumn{2}{c}{ FATHER SCORES } & MOTHER ECORES \\
CLUSTER & MEAN & SD & MEAN & SD \\
Hostile & 1.728 & $.4 \Xi$ & $1.69 \Xi$ & $.4 \Xi$ \\
Domiriant & 1.860 & .45 & $1.71 \Xi$ & .35 \\
Friendly & $\Xi .709$ & .48 & 2.855 & $.4 \Xi$ \\
Submissive & 1.648 & .31 & $1.79 E$ & $.3 E$
\end{tabular}

These results appear to be corsisterit with the riorms provided by Lorr arid MCNair (1968) for the IEI. They listed the average mean cluster scores as: Hostile: 1.73; Dominant: 1.98; Friendly: E.38; and, Submissive: 1.85.

As indicated by the above results, fathers were perceived as having beer predominantly friendly, followed by dominarit, hostile, and finally submissive. Mothers, Gri 
the other hand, were perceived as having beer predominaritly friendly, but then as submissive, then domirant, and lastly hostile.

For exploratory purposes, the interaction of sex of the respondant and responses to the Mather arid Father IEIs was examiried. A summary of the results is as follows:

TAELE こ

IBI CLUSTER SCORE MEANS AND STANDARD DEVIATIONS

BY RESPONDENT SEX

\begin{tabular}{|c|c|c|c|c|}
\hline \multirow{2}{*}{\multicolumn{5}{|c|}{ FATHER SCORES }} \\
\hline & & & & \\
\hline Hostile & 1.764 & $.4 E$ & $1 . E 77$ & $.3 E$ \\
\hline Dominant & 1.913 & .44 & 1. 698 & .3 \\
\hline Friendly & E. 748 & $.4 E$ & E. 854 & \\
\hline Submissive & 1. 658 & .35 & 1.797 & .3 \\
\hline \multicolumn{5}{|l|}{ EEMMELEES } \\
\hline Hostile & 1.700 & .44 & 1.698 & .4 \\
\hline Dominarit & $1.84 \square$ & $.4 E$ & 1.7シ巾 & .3 \\
\hline Friendly & ㄹ. 713 & .48 & $\approx .84 E$ & .4 \\
\hline Subrnissive & 1. 634 & .29 & 1. $802 \equiv$ & \\
\hline
\end{tabular}

Both males arid and females saw their mothers as more friendly and submissive ard their fathers as more dominart. A manova comparing the cluster score mearis revealed rig statistical significarce betweer the male arid female groups.

Although the demographic composition of this sample resulted in only a very small percentage of subjects $(N=E \cdot 4$ ) whose family composition had uridergore some majar charge 
since they were ages 0-7, the opportunity was used to identify this group and to simply look at their resporise characteristics for informational purpeses. Their means and standard deviations are summarized below and compared to the rest of the sample.

\section{TABLE 3}

IBI CLUSTER SCORE MEANS AND STANDARD DEVIATIONS BY FAMILY COMPOSITION STATUS

\begin{tabular}{|c|c|c|c|c|}
\hline INTACT FAMILY & FATHER & RES & MOTHER & SCORES \\
\hline Hostile & 1. 705 & .39 & 1. $E 5 \Xi$ & .37 \\
\hline Dominant & 1.843 & .42 & 1. 695 & .33 \\
\hline Friendly & こ. 729 & .47 & Е̇. 884 & .40 \\
\hline Submissive & 1. $E 38$ & .31 & 1. $B \backsim=$ & $.3 E$ \\
\hline DISRUPIED EAMILY & & & & \\
\hline Hostile & 1.879 &.$E Q$ & 1. $9 \Xi 9$ & .58 \\
\hline Domi riant & 1.973 &.$E 1$ & 1.817 & $.4 \theta$ \\
\hline Friendly & ᄅ. 581 & .54 & ह.. 689 & $.5 E$ \\
\hline Submissive & 1.713 & .33 & 1.761 & .35 \\
\hline
\end{tabular}

Taking the limited sample irto careful corisideration, some interesting differences are roticed in the resporises af the subjects who have had some charge ir the family betweer the ages arid 7 ard the preserit. Mothers were ideritified as more hostile than they were in any of the ather subject groups. While ir, all other groupings, mothers are seer, ir, rarke order, as 1) frieridly, 2) submissive, 3) domiriart, 4) hostile, in this group of subjects mothers are seeri as 1) friendly, 2) hostile, 3) domirart, ard 4) submissive. It 
is also the orly group in which mathers are seer as more hostile thar fathers. Mothers in the dismupted group were also seer as mare dominarit and hostile than the mothers ir the iritact group arid less submissive. Fathers as well were seer as mare hostile and domiriarit as well as mire submissive by respondarits from dismupted fanily thar ty respondarits from intact families. Similarly, both mothers ard fathers were seen as less frierdly by the dismupted group than they were by the iritact group.

As meritiored ir the Method sectibr, the IEI uses a resparise ratirg scale of 1 through 4 . The respirises abtained ar the IEIs in this sample of college studerits utilized the full spectrum. Resporise rarige for the varibus clusters are as follows:

TAELE 4

AVERAGE RESPONSE RANGES FOR IEI CLLSTER SCDRES

$\begin{array}{lcc}\text { Mother } & \begin{array}{c}\text { Father } \\ \text { Scores }\end{array} & \text { Scores } \\ \text { Hostile } & \text { E. EE } & \text { E. } 16 \\ \text { Domirarit } & \text { E.48 } & \text { E. } \\ \text { Friendiy } & \text { E.1E } & \text { E. } 16 \\ \text { Submissive } & 1.63 & 1.89\end{array}$

When the sex of the resporidarit arid family compositior are examined the rariges are as follows: 


\section{TAELE 5}

\section{AVERAGE RESPDNSE RANGES FDR IBI CLUSTER SCDRES EY RESPONDENT SEX AND FAMILY COMPOSITION STATUS}

FATHER SCORES

\begin{tabular}{|c|c|c|c|c|}
\hline & Male & Female & Iritact & Disrupted \\
\hline Host ile & 1.68 & ᄅ. $\epsilon \in$ & 己. 17 & ᄅ. 48 \\
\hline Domi riarit & 2. 28 & 2. 48 & 2. $3 \epsilon$ & E. 4E \\
\hline Frieridly & 2. 1 & อ. $1 \bar{c}$ & $E .11$ & 1.84 \\
\hline Subrnissive & 1.49 & 1.58 & 1.62 & 1.38 \\
\hline
\end{tabular}

MDTHER SCORES

$\begin{array}{lcccc} & \text { Male } & \text { Female } & \text { Iritact } & \text { Dismuded } \\ \text { Hostile } & 1.7 E & 2.1 E & 2.16 & 1.98 \\ \text { Domiriart } & 1.70 & 2.00 & 1.71 & 1.5 E \\ \text { Fmieridy } & 1.88 & 2.07 & 1.67 & 1.91 \\ \text { Subinissive } & 1.58 & 1.89 & 1.89 & 1.54\end{array}$

Males appear to use a narnow resporise rarige in resporidirig to both IBIs as compared to females. The greatest variability caccurs ir female's perceptions of their fathers, arid the least in males perceptigris of their mothers.

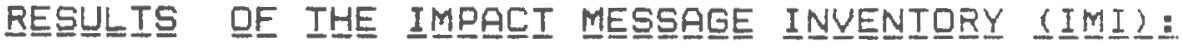

The Impact Message Irveritary (IMI) was compieted by ore hundred sixty three subjects after viewirig a short videctape of a psychotherapist iritroducing them to psychothemapy. As with the IEIs, results were tabulated and corverted irto "cluster" scores. The mean scomes and staridard deviatiars are as follews: 


\section{TABLE $E$}

IMI CLUSTER SCORE MEANS AND STANDARD DEVIATIONS

$\begin{array}{lll}\text { CLUSTER } & \text { MEAN } & \text { SD } \\ \text { Hostile } & 1.439 & .4 \Xi \\ \text { Domiriart } & 1.539 & .35 \\ \text { Frierdiy } & \text { E.585 } & .4 E \\ \text { Submissive } & 1.6 \Xi 4 & .29\end{array}$

These mean cluster scares fall within the marige of cluster scores reported by Kiesler (1984) ir his research hardoogk. As iridicated above, the therapist was perceived as predominartly frieridy, followed by subnissive, doririarit, and hostile. (It will be remembered that this is the sane prafile the was given to mathers or the Iriterpersamal Behavior Iriveritary.)

Agair, as was the case with the IBIs, the iriteractiar of sex of resporidarit ard resporises on the ImI was explarec. A summary of the results are as follows:

\section{TAELE 7}

IMI CLUSTER SCORE MEANS AND STANDARD DEVIATIONE BY RESPONDENT SEX

CLUSTER

Hostile Dominant Friendly Submissive
MALES

$\begin{array}{ll}1.507 & .48 \\ 1.569 & .35 \\ 2.634 & .44 \\ 1.720 & .35\end{array}$

FEMALES

1.483

1. $52 \Xi$

Eं. $5 \in 3$

1.577
.38

.35

.47

.24

Both males arid fernales produced the same ordering of 
clusters in rating the therapist. Males, however, scored all of. the clusters higher thar did females. A MANOVA comparing the cluster score mearis did iridicate a statistically sigrificarit differerice between the male ard fernale scores on the subnissive cluster. The practical significarice of this difference may be small given tine actual differerices in the mearis arid their positiar ar a four poirit rating scale. However, it may indicate a trerid that may be worth explorirg further in other studies.

When the average range of the ratirigs ori each cluster is considered, notable are particularly the restricted range. for males on the dominarit cluster arid the restricted range for females on the submissive cluster.

TAELE B AVERAGE RESPONSE RANGES FOR IMI CLUSTER SCORES EY RESPONDENT SEX

\begin{tabular}{|c|c|c|}
\hline CLUSTER & MALES & FEMALES \\
\hline Hostile & อ. 11 & E. $\theta B$ \\
\hline Domin riant & 1. 28 & 1.83 \\
\hline Frieridly & 1.78 & E. 11 \\
\hline Submissive & e. $\Delta$, & \\
\hline
\end{tabular}

Since the degree of variability of resporises to a constarit stimulus therapist was ore of the major exploratory questions of this study, ari arialysis of the distribution of cluster scares was undertaker. After 
corverting the cluster scores to standard scores the following characteristics of the eritire resporise distribution was assertained. Ratirigs of the therapist or the hostile cluster were withir cine stardard deviation above or below the ipsative mear for Hostile cluster scores 77. E\% of the time. 1E. $8 \%$ of the ratings were between 1 ard 2 standard deviaticirs from the mear, and $5.6 \%$ were mare thar $z$ staridard deviations above or below the mear. For the Dominart cluster, $73.3 \%$ of the ratings of the stimulus therapist were withir orie stardard deviaticir of the mear. 21. $1 \%$ were betweer 1 arid $E$ staridard deviatigris, arid $5.6 \%$ were ratirgs greater than E staridard deviatioris from the mear. For the Frieridy cluster, EE. $7 \%$ of the ratirige af the stimulust therapist were withir 1 staridard deviatior af the meari. $36 \%$ were between 1 ard $E$ staridard deviatioris, arid 1. $2 \%$ were more than $\Xi$ staridard deviatiors from the mear. Finally, for the subrissive cluster, 80.7\% of the ratirigs of the thenapist were withir 1 stardard deviatiar af the mear. 14.9\% were betweer 1 ard $e$ staridard deviatiars arid 4. 3\% were greater thar $Z$ staridard deviations from the mear. The more specific distribution of cluster scares car be seen by plottirig the cluster score frequericies (see Table 9). 
IMI CLUSTER SCORE FREQUENCIES

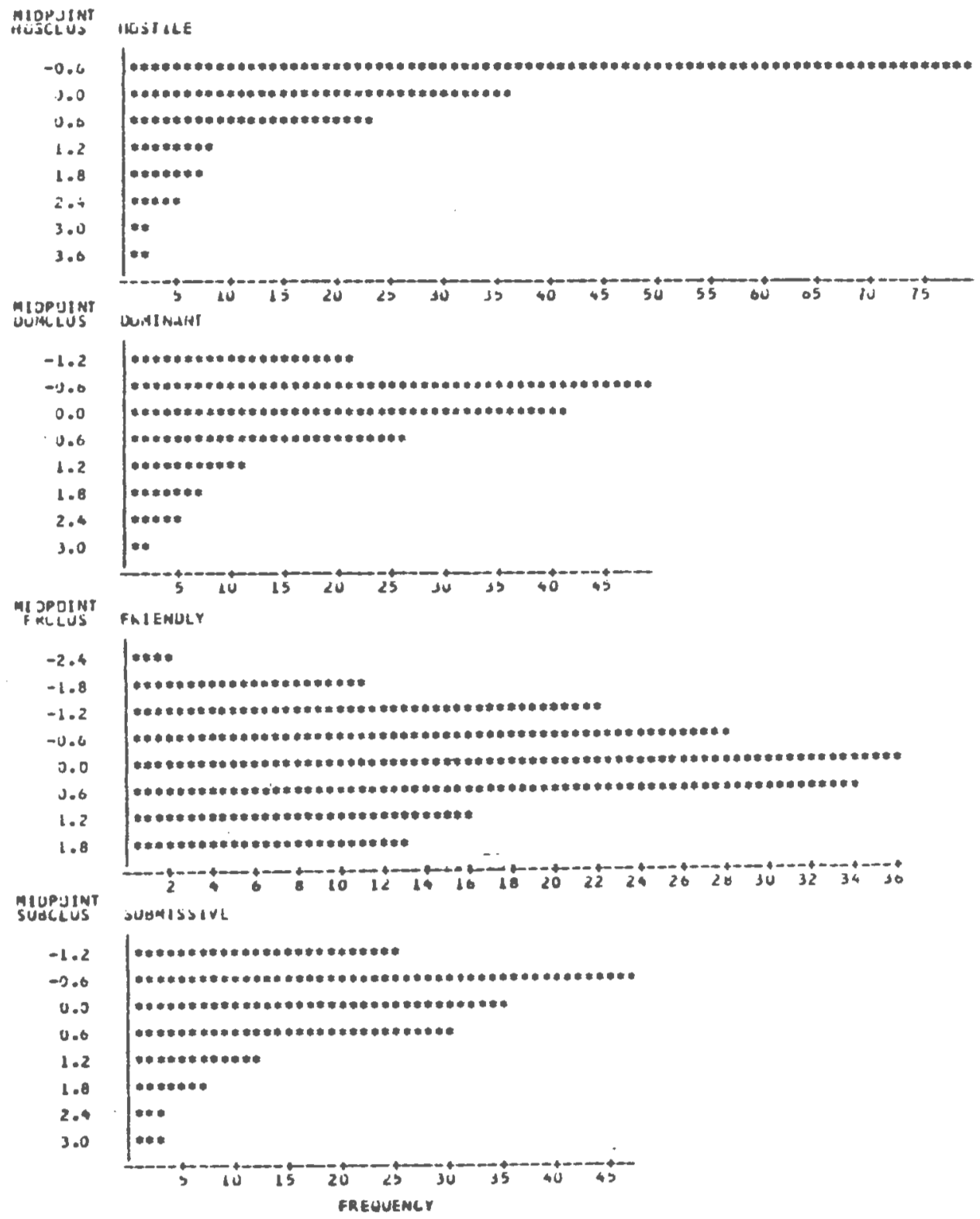


The iriteraction of family composition status (i.e. whether or not there had beer charges ir family compostion since the respordant was 7 years of age) was again explored, as with the IBI, far iriformatiaral purposes. As mentioned previously the sample was largely represerited by individuals with family which stayed iritact to the preserit. Only 23 individuals wha completed the IMI identified their family compesition as having charged. A summary of results takirg this iriteractigr irita consideraticin is as follows:

TABLE 10

IMI CLUSTER SCORE MEANS AND STANDARD DEVIATIONS BY FAMILY COMPOSITION STATUS

\begin{tabular}{|c|c|c|c|c|}
\hline \multirow[t]{2}{*}{ CLUSTER } & \multicolumn{2}{|c|}{ INTACT } & \multicolumn{2}{|c|}{ DISRUPTED } \\
\hline & MEAN & SD & MEAN & SD \\
\hline Host ile & 1. 424 & .41 & 1. 530 & .4 \\
\hline Dominant & 1. $5 \Xi E$ & .34 & 1. $E 17$ & .4 \\
\hline Friendly & E. 593 & .47 & E. $501=$ & \\
\hline Submissive & 1. $E \geq \overline{3}$ & .28 & 1. $E=\Xi$ & \\
\hline
\end{tabular}

TABLE 11

AVERAGE RESPONSE RANGES FOR IMI CLUSTER SCORES BY FAMILY COMPOSITION STATUS

$\begin{array}{lcc}\text { CLUSTER } & \text { INTACT } & \text { DISRUPTED } \\ \text { Hostile } & 2.11 & \\ \text { Dominant } & 1.83 & 1.61 \\ \text { Friendly } & 2.11 & 1.50 \\ \text { Submissive } & \text { 2. } & 1.67\end{array}$


Subjects from disrupted fanilies rated the therapist as more hostile and more dominart thar did subjects from intact families, whereas subjects from still iritact families rated the therapist as mare friendly thar did subjects from now dismupted fanilies. Taking the rarige of ratings into corisideration, it is also noted that a greater rarige is used by subjects from still iritact families, whereas subjects from dismupted families use a mire restricted range ir their rating of the therapist, ar aII clusters.

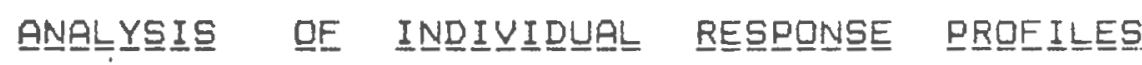

Iridividual profiles of cluster scores for the IMI ard IBI respenses were graphed arid compared visually arid using a schema and carrelatior procedure barrowed fram Activity Vector Arialysis (w.V. Clark Assaciates, 1958). Usirig this method each profile was giveri an ipsative coding which allowed profiles to be compared and to be giver a correlation coefficient reflecting their similarity (ir terms of shape). The profile obtained by a subject's ratirg of the stimulus therapist on the IMI, was compared with each of the profiles obtained for the subject's ratirigs of their parents using the IBI. (Copies of the graphic representations of each subject's three profiles may be obtairied from the author.) 
Correlation coefficierits obtaired by such comparisoris ranged from -.75 to +1 . Q a a d are listed in Appendix F. Of the two correlation coefficients produced (IMI and Father IBI, IMI and Mother IBI), the larger value was chosen arid used in the canonical correlation analysis. Seventy-four percent of the "choser" IBI profiles received a correlatiari coefficierit of. 8 or greater wher correlated with thier IMI response profile. Usirg the profile arialysis, EZ\% of the IMI profiles were found to be mare similar to the profile produced by the subject's resporises or the IBI characterizirg their mother, while the other $38 \%$ nad more similarity between their IMI profiles and the IBI characterizing their father.

Analysis of the profiles revealed very vividly several triends that almeady have been made note of in reviewing the other results. For iristarice, the clear dimiriarice af the Friendly cluster ir the profiles is remarkable. This was very consistent in resporises to both the IMI arid IEI. Furthermore, wher viewed graphically, the high cargruerice between the shape of the profiles of IMI ard IBI resporises for a large proportion of the subjects is remarkable. There are, however, also those very interestirig examples (르5\%) where this high congruence is lacking arid where ti becomes clear that there is distinct variability in how parental figures and the stimulus therapist are perceived. 
Studying the graphic presentation of the individual IMI profiles was also particularly revealing as it agairi visibly pointed out the individual variability ir how a constant stimulus was perceived. This was particularly noticeable in this format where the data was not reduced to group means. Differences were evident not orily ir the differential quantitative values given to the clusters but also in the differential relative orderirg of clusters for some individuals. Some individuls thus saw the therapist 25, for instance, being predomirantly hostile while the overwhelming concurrarice or the part of the group was radically different.

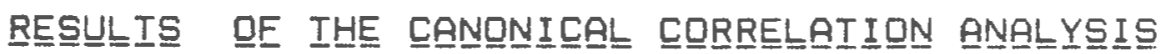

A canonical comrelatior aralysis was performed betweer subject's ratings of a constarit stimulus therapist or the Impact Message Iriveritory (IMI) arid the most highly comrelated set of ratirgs of a parerital figure on the IBI. The intra and intercomrelatior coefficierits of the IMI and the IBI scores used in the canonical correlatior are preserited below. 
TABLE 12

CORRELATION MATRIX OF IMI AND IBI CLUSTER SCORES

\begin{tabular}{|c|c|c|c|c|c|c|c|c|}
\hline & $x 1$ & $x 2$ & $x_{3}$ & $x_{4}$ & xs & 20 & $x 7$ & $x$ \\
\hline 1 & 1.0090 & 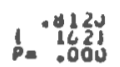 & 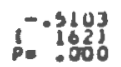 & b. $\begin{array}{l}3471 \\
1621 \\
: 000\end{array}$ & $\left\{\begin{array}{r}1434 \\
6021 \\
6007\end{array}\right.$ & 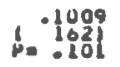 & $\begin{array}{r}-.0592 \\
1.021 \\
1.22\end{array}$ & \\
\hline & 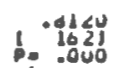 & 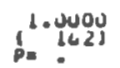 & $\begin{array}{r}-.2923 \\
1.021 \\
1.000\end{array}$ & b. & 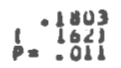 & $\begin{array}{r}.0123 \\
16.021 \\
0.180\end{array}$ & $\begin{array}{r}-.0040 \\
b=1621 \\
.202\end{array}$ & \\
\hline & 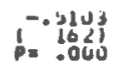 & 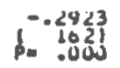 & t.jous & & & 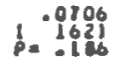 & & \\
\hline & 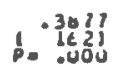 & 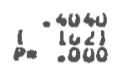 & $\begin{array}{c}1216 \\
162 j \\
0.062\end{array}$ & b. 1.0 & 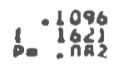 & 1. $\begin{array}{r}.2359 \\
1021 \\
.001\end{array}$ & & \\
\hline & $\begin{array}{c}1.1454 \\
162 \\
0.007\end{array}$ & f. & $\begin{array}{l}-.0965 \\
1.021 \\
0.9111 \\
.111\end{array}$ & b. $\begin{array}{c}0.1040 \\
1021 \\
.082\end{array}$ & $a^{1.00 u y ~}$ & 1. $\begin{array}{r}6002 \\
102 \\
1000\end{array}$ & $\begin{array}{l}-.3430 \\
1.020 \\
0.000\end{array}$ & \\
\hline & 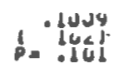 & 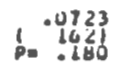 & 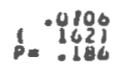 & & 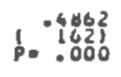 & & & \\
\hline & $\left\{\begin{aligned}-.0252 \\
1021 \\
0.22\}\end{aligned}\right.$ & $\left\{\begin{aligned}-0660 \\
1620 \\
.201\end{aligned}\right.$ & & & $\begin{aligned}-.5536 \\
p= \\
p=000\end{aligned}$ & 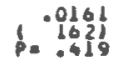 & $\begin{array}{l}1.0000 \\
1.021\end{array}$ & \\
\hline & 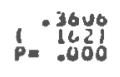 & p. $\begin{array}{c}5202 \\
1621 \\
1000\end{array}$ & $\begin{array}{rl}-r & 1323 \\
1623 \\
6020\end{array}$ & 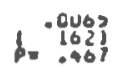 & p. & 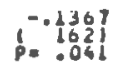 & 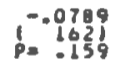 & \\
\hline
\end{tabular}

SCOCFICLLMT, ICASLb) / SIGMLFICANCEI

The canonical correlation analysis performed betweem the IMI ard the most highly correlated parerital IEI car be summarized as follows:

TAELE 13

SUMMARY OF CANONICAL CORRELATION ANALYSIS OF IMI AND IBI CLUSTER SCORES

Canonical

Variate

$\begin{array}{ll}1 & 0.16719 \\ 2 & 0.7710 \\ 3 & 0.00795 \\ 4 & 0.00089\end{array}$

Canorical

Correlation

D. 40889

0. 27766

D. 08918

0. 02977
${ }_{V}^{\text {Bartiett's df }}$

$\begin{array}{rr}4 E .58 & 1 E \\ 13.94 & 9 \\ 1.39 & 4 \\ 0.14 & 1\end{array}$


A pl. O1 criterion level of significarice reveals that only one of the canonical correlations is statistically significant. This canonical correlation, represeritirg the maximum relationship between the carionical variates IMI arid IBI profiles, resulted in only a $16.72 \%$ shared vamiarice.

The canonical structure vectors associated with the significant canonical variates for the IMI and IEI are as follows:

\section{TABLE 14}

STRUCTURE VECTORS OBTAINED FROM CANONICAL CORRELATION ANALYSIS OF IMI AND IBI CLUSTEF: SCORES

$\begin{array}{lrrr} & \begin{array}{c}\text { Caronical } \\ \text { Variate }\end{array} & & \begin{array}{c}\text { Cariorical } \\ \text { Variate I }\end{array} \\ \text { IMI-Hostile } & & & .934 \\ \text { IMI-Dominant } & .840 & \text { IEI-Hostile } & .434 \\ \text { IMI-Frieridly } & -.594 & \text { IBI-Damiriarit } & .041 \\ \text { IMI-Submissive } & .089 & \text { IBI-Friendly } & -.241 \\ & & \text { IBI-Submissive } & .969\end{array}$

As indicated above, an examiration of the magritude arid direction of the structure coefficients associated with the IMI revealed a profile marked by a low frieridy cluster, followed by the Submissive cluster, a rather high Dominarice cluster, and a peak or the Hostile cluster. Similar examination of the structure coefficients associated with the IBI reveal a profile again with a low point or the Friendly cluster, but followed by Dominance, Hostility, and a peak on the Submissive Cluster. 
An arialysis of the amount of reduridaricy betweer the IMI and IBI reveals the following information:

TABLE 15

SUMMARY OF REDUNDANCY ANALYSIS BETWEEN

IMI AND IBI CLUSTER SCORES

\begin{tabular}{|c|c|c|c|c|}
\hline $\begin{array}{l}\text { Carionical } \\
\text { Variate }\end{array}$ & Rc & $e_{R C}$ & $\begin{array}{l}\text { Aver. Sq. } \\
\text { Loading }\end{array}$ & Reduridaric \\
\hline IMI 1 & 0.40889 & $.1 \in 719$ & .48474 & .08104 \\
\hline $\operatorname{IMI} 2$ & 0. $277 \varepsilon E$ & .07718 & .27392 & - VẼ11E \\
\hline IMI 3 & 0.08918 & .02795 & .13986 & - QRQIi1 \\
\hline $\operatorname{IMI} 4$ & D. 82977 & - & .10149 & 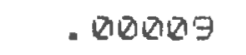 \\
\hline IBI 1 & 0.40889 & .16719 & . :ं3E88 & .104964 \\
\hline IBI $Z$ & ๑. 27766 & .07710 & . 26883 & ・ロシロマこ \\
\hline IBI 3 & 0. 08918 & .08795 & . 3Еマ35 & . 010255 \\
\hline IEI 4 & D. 02377 & . Danas & .11394 & - vidaia \\
\hline
\end{tabular}

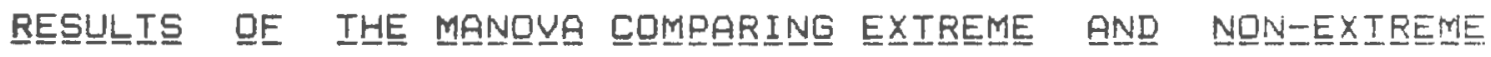
GRQUPPS

A MANDVA was performed comparirg individuals who rated their parents as having a more extreme iriterpersoral interaction style and those who did not, to determine whether or not these differerices in perception larid perhaps experience) of parerital interpersonal behavior were related to how the subject perceived and rated a stimulus therapist in the preserit.

Lorr, Bishop, and MeNair (1965) had identified individuals whose mean scores on the IBI were at least one 
standard deviation above the norm as being "extreme" and found that this classified somewhat less than half of all patient profiles. In the sample of IBI scores obtained ir this study, it was found that if the eight cluster scores (four for mother and four for father) were corsidered, a cut off point of three cluster scores (of the eight) one standard deviation or more above the group mearis was needed to establish extreme and non-extreme groups. The two sets of IBIs were considered together (therefore eight cluster scores) sirice there was no theoretical reason to suggest that "extreme" interpersonal characteristics of one or another parent were more important. The MANQVA comparing these two groups found that there were no sigrificarit differences in the group's ratings of the therapist using the IMI $(=.51)$. Careful consideration of these results raised the question of whether" "extremeness" ir cre direction or arother was more important theoretically ir terms of the hypothesized impact on present perception, and whether or not including "extreme" scores in either direction "washed out" statistical results.

A second MANOVA where "extremeness" was more specifically defined as two or more cluster scores rof eight) one staridard deviation or more beyond the mean iri the Rositivive direction (e.g. greater hostility, greater dominance, etc.) yielded significant results. The overall 
MANDVA was significant at the $<.05$ level. An F statistic of 3.07 with 4 and 155 degrees of freedom was obtained. Univariate ANOVAs were also performed. The obtaired summary statistics are as follows:

TAELE $1 E$

SUMMMERY STATISTIES EQR UNIVARIAIE ANALYYSEES

\begin{tabular}{|c|c|c|c|c|}
\hline & & $F$ & $d f$ & $P$ \\
\hline HOSTILE & $\begin{array}{l}S S=24.83391 \mathrm{Z} \\
M S=\square .157176 \in 6\end{array}$ & 5.23 & 1,158 & $0.02: 35$ \\
\hline DOMINANT & $\begin{array}{l}S S=18.663850 \\
M S=0.11812563\end{array}$ & 11.24 & 1,158 & Q. Q \\
\hline FRIENDLY & $\begin{array}{l}S S=33.393225 \\
M S=0.21134952\end{array}$ & 0.00 & 1,158 & 0.3864 \\
\hline SUBMISSIVE & $\begin{array}{l}S S=11.097623 \\
M S=0.7023812-01\end{array}$ & 1.75 & 1,158 & Q. $187=$ \\
\hline
\end{tabular}

It was thus found that both the hostile arid domiriant cluster scores were significant indicating that subjects who perceived their parents as more extreme ir the hostile and dominart categories also rated the therapist more extremely. 


\section{DISCUSSION}

Several hypotheses have been addressed in this study, all concerned with the nature of the perception of therapists and the variables associated with such perception. The variables associated with the perceptigr of a therapist ard the experierce of an iriteractior with a therapist have beer, dealt with exterisively withir the psychoanalytic traditior. The concept of trarisference as explicated in that tradition mairitairs that the perceptian of a therapist within the psychoaralytic situatior: 1) differs with individuals; e) is related to previals behavioral, cogritive and affective experierices with sigrificart others; and, 3) provides the mast succinct ard lasting avenue for change.

The experimental situation provided by this study offered a way of beginning to explore some of these aspects of transference and therapist perception arid to assess a potential method for operatiaralizing the coricept for further study. The degree of variation in how a Iarge sample of normal individuals (college studerts) would perceive the same therapist was explomed, as was the possible correlation of such variation in perception with the recalled parental interpersonal style duririg eariy childhood. 
The results obtained in testing the varigus hypotheses were generally supportive and have fulfilled the exploratory nature of this study as well as suggestimg mary further Iines of irvestigation which would not have beer clearly demarkated without the iriformation collected from this study. More specifically, to review, hypothesis are, which addressed the variability of subjects" perceptiors af a therapist, was clearly supported ard indicated that there: is considerable variability in hew a therapist is perceived. Secondly, the relationship betweer this variability in perception across individuals ard the perception of individuals' parents as they were remembered as being during early childhood (hypothesis two) was follud to be supported wher, comparisors of ipsative profiles of subjects' cluster scorings of their perceptiors af the therapist ard of their cluster scarirgs af their pareritai figures were made. However, a discreparicy betweer these ipsative results and insignificarit results of a caroricel correlatior arialysis of the cluster scores suggested a reed for further exploration bath of the thesretical corstruct of transference and of the methods of measumemerit arid analysis. Finally, tests of hypothesis three fourd that individuals who perceived one of their parents as having had an "extreme" interpersonal style (particularly ir the areas of hostility and dominarice) did indeed also perceive the stimulus therapist as mare interpersorially "extreme". 
As indicated by the already completed theoretical discussion of the concept of trarsfererice, the existarice of variability in the perception of a therapist is at the very core of the concept and is in fact axiomatic. The rature of the variability and the point at which it gccure is something to be further studied. The purpose of this study was to lay some groundwork ard perhaps provide a framewirk. for ar understanding of the corcepts invalved. Thus, ir this study, the initial exploratory questior af the degree of variability in how gree therapist is perceived is a central one both for this study arid for ar uriderstaridirig af the nature of therapist perception arid the more irvolved concept of trarisference discussed in the psychaarialytic literature. Ir this study it was fourid that giver a constant stimulus of a therapist introducing psychatherapy on a videotape, there was corsiderable variability ir the range of responses.

As discussed earlier, the Impact Message Iriveritory, which was used to assess subject's perceptioris bi the stimulus therapist, is an instrumerit whicn focuses or the covert affective, cognitive, and behaviaral engagemerits which individuals produce in each ather. Thus, the subjects in this study were characterizirig the therapist by how he would "make them feel", what they thought he willd feel and think about them, and in gerieral how they 
perceived him as coming across as a person and therapist. Because of this unique approach towards assessmerit of the interpersonal style of a target person, valuable infomatiar about the perceptual framework of the resgonderit, or ir transference terms, about the iriherent individual variarce or 'distortion' in how each individual construes ariother and their interaction with them, car be obtaired. This experiment, in holding the target stimulus constarit, allows for a more careful exploration of this pheriomerion.

Results of the IMI assessmerits of the target therapist indicated ar greeral 1 l assessment of the therapist by the group of subjects as predorinantly frieridly, followed by submissive, domiriant, and hostile. These results are consistent with findings obtained by same other studies using the IMI although in very different desigrs. Hudgine arid Chirico (1983) found psychotherapy interns wher rated, peaked on the Friendly cluster, followed by Submissive, and then weaker impacts or the Hostile arid Doririarit clusters. (High Frieridy cluster scores were also faurd among assertive individuals Llabe-slaar, 138E; Reagar, 1978, 1979) and are also nommatively fourd on the Interpersonal Behavior Inveritory, upor which the. IMI is based. )

Given this overall average assessmerit of the target stimulus therapist by the group, there was importart variability which was ideritified both iridividually ard ar a 
group level. A viewing of the rarge ard distributior statistics indicates that the identical stimulus was irifact perceived as markedly different by some subjects. Furthermore, the individual platting of ipsative profiles of the cluster scores revealed very graphically that there were differences both in terms of the level of cluster score ratings, and also in the cluster orderings for individuals. Thus, not only did individuals differ ir how relatively friendly or hostile they felt the therapist was, but in some cases differed radically from the group ir their overall characterizatior of him by, for example, seeing the therapist as predomiriarily hostile. Such differences arid the speculation about the reasoris for their existarice are at the very basis of the corcept of transference. It has, of course, been hypothesized from the psychoanalytic viewpoint that the rature of the perceptual process withir the therapeutic relationship is deeply influenced by early experiences with primary figures (early object relations).

For exploratory purposes, it was questioried whether sex or family composition of the respondarit appeared to be a factor in the variability which was obtairied in IMI ratings. Male and female differences appeared to be negligible, although there were found to be statistically significant differences on the submissive cluster with 
males rating the stimulus therapist as more submissive thar females, perhaps suggesting that as a group, males were particulamly sensitive to this stereotypically more female trait in a male. These differences have to be corsidered extremely carefully however, because the differerices are very small and males on the whole tended to give higher scores on all the clusters. Males also had the most restricted range (perhaps indicating the highest concmuerice) on the Dominarit cluster, while females, on the other hand, had a much mare restricted rarige on the Submissive cluster. Interestingly eriough, these two clusters might be thought of as the clusters which could be most clearly tied to stereotypic sexrole characteristics. Male and female subjects in this experimerit appear to have the most concruence ard definiticr withir their sex ir rating a target persor within these dimerisions. Thus while there are no indicatiors of practical sigrificarice betwer. the sexes in their perceptian ir this experimert, same trerds which $\mathrm{might}$ be watched ir further research have beer, noted.

Stability of family compositior irita the preserit was also considered as a variable (on ar exploratory basis) ir: investigating the variability in the perception of the target therapist. While the overall pattern of assessmert of the therapist did not differ, when this variable was considered there were some small trends which were of 
interest and might suggest further investigatiar although they could not be difinitively addressed in this study. It was fourd that subjects from families whose family composition had beeri disrupted sirice the subject was age 7 , rated the stimulus themapist as higher on the Hostile ard Dominant clusters ard lower or the Frierdly cluster thar did their counterparts. These subjects had a riarrawer range in their reporises on all clusters, suggestirga greater concruence in their specific patterr of perceptiors which might be related to membership in this griup. Ore might hypothesize, of course, especially from a transference poirit of view, that iridividuals from families who have undergone some dismuption have iritrojected the qualities associated with major dismuptichs amorgst those that ore loves (greater hostility and domirarice, ard less friendiness) and now are more prore to project these feelings and perceptions onto a reutral other arid see then as more hostile, domiriart, and less frieridy.

While both the factors of sex and statility of family compostion suggest some interesting iriteractiors, the variation seen purely in the realm of iridividual differences also remains most compelling. As mentiared earlier, while some of these differerices are last ir a group analysis, the intersubject variability remains clear, particularly wher viewing the frequency distributiors of 
cluster scores and the ipsative profiles arid orderings of cluster scomes. The psychoaralytic coricept of transfererice maintains that these individual differerices in perceptich can be seen as relating at least in part to the interpersonal experience of the individual with their "primary objects" (parental or caregiving figures) durirg early childhood. This study attempted to look at this explarition for individual variation in the perceptiar of a therapist by gathering information about how the subjects remembered seeing their parerits iriterpersonally wher they were young, categorizing it in the same dimensiars provided by the IMI (the four cluster scores), arid exploririg a correlation betweeri the two.

The two ways in which the iriterpersina? characteristics of the stubjects" parerits las they were remembered as being when the subjects were between the ages of $D$ and seven) and the interpersorial characteristics perceived in the presented therapist were compared produced somewhat conflicting results. While a visual arialysis of the IMI and IBI cluster score profiles ard correlations obtained by coding and comparing the correlations obtaired by coding and comparing the shape of the profiles yielded what appeared to be a high complation, the caroricial correlation analysis indicated that there was very little correlation or overlap between the results obtairied usirg the two instruments. These differirig results instill some 
confusion in the study at hand and require careful consideration.

One possible explariation for the discrepancy of these results may be in the nature of the types of analyses. The graphirg arid coding of the cluster score profiles was orily performed secordarily to determine the relative degree of correlation between the mother or father IEIs arid the IMI profile. The visual represeritation of the profiles was however quite compeliling as was the degree of correlatigr obtained for the large majority of sets of profiles. It must be remembered, however, that these are relatively less sophisticated methods of analysis as compared to the canonical correlation analysis. The AVA codirg techrique arid resultarit correlation, for instarice, only take irito account the shape of the profiles, while the ather properties are neglected. Or the other hard, there exists a certair degree of face validity in this approach in that: 1) it uses an ipsative level of measurement which has a certain consistency with the concept of transference as it is understood clinically and theoretically; arid, E') the concentration on the shape of the profile of cluster scores seems to infact also be intuitively the most critical element in consideration of the coricept of transfererice,

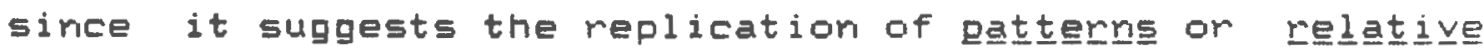
perceptual importance assigried to interpersonal traits. 
Height and of the profiles would seem to be of less significance to the concept. For these reasons, wher there appeared to be a major discrepancy in the degree of correlation suggested by the two methods, results af the ispative appraach were not completely disregarded as might have been done in ather circumstances.

The canonical correlation analysis, on the other harid, provides a very statistically exacting way of determirimg the degree of linear relatiorship betweer lirear combinations of variables (the clusters) ir the IMI ard IBI. The approach is, hawever, very differerit ir that it is a procedure utilizing sample statistics as apposed ta purely individual, ideographic data. As iridicated above, the results utilizing the canonical correlation aralysis indicated that there is in fact very little correlatior between the dimensions being measured by the two instrumerits, and that giver the resporises from are of the instruments, little car be predicted about resporises or the other.

These results are disappointing. Most directly they suggest (at least when using this method of aralysis) that the perceptions or ratings of the impact of the stimulus therapist are not related to the ratings of parerits as the subjects remembered them to have been during early childhood. It had, of course, beer, hoped that a correlation betweer these two ratings would offer a mears 
of looking at what has been defiried as trarisfererice phenomena.

Hawever, several aspects of transference need ta be cansidered when reviewing these results. Transference has been traditionally spoken of within the context of the psychotherapeutic relationship and seen as ar outgrowth gf the development of that relationship. Crederice has, however, also been giver the the existarice af ar iritial trarsference reaction which is not deperiderit on the fuli development of a therapeutic relationship but is rather ar iritial perceptual caristrual of the therapist. The question for this study has remained whether such a reaction could in fact be measured usirg statistical techniques. The results in this study aremixed ir this respect. One possibility that has to be considered is that in fact the transferentialiy irifiuerced perception that could be measured by this study would have to be quite extreme arid constarit to be picked up statistically. There are two potential variables which could affect such a possibility: the nature of the resporiderits or the rature of the stimulus.

Clinical and theoretical knowledge about trarisfererice would suggest that although the process is a ubiquitgus one, the degree of distortior or rigidity in its expressiari would vary depending or the degree of psychopathology. 
Thus, the potential for obtaining enough distortior for statistical significance may have been uriderestimated giver, this nornal population. My long term interit of experimenting with the use of the IEI ard IMI has beer to use it to study transference arid its development arid resolution with an actual clirical populatior. Ore might expect that such a population would provide for mare perceptual distortior. However, it was hoped that sime baselire information both about the corcept of trarisfererice and the instrumentation could be obtairied by the presert study.

Arother factor poteritially related to the possibility that "extreme" erough results were rict obtained may be the use of a one-time videctaped preseritatiori. As meritioried above, the rature of the trarisference to be "picked up" by an iritial impression is in itself differerit although equally valid. The additicral factor of this beirig a videotaped stimulus may, however, have made the reactians a bit more muted. Kiesler (1984), ir his research hardbook. suggested that ratings of actor/strargers cir videgtape sean to have produced the lowest impacts in some studies.

The results of the MANDVA comparing subjects with extreme scores on their parental IBIs to those without extreme scores seem to suggest that if taker as a whole, no clear relationship can be seen bettweer results of the IBI and IMI. However, when further specificatior, is made about 
the nature of the "extremeness" a direct relatedness was established. In fact the results of the MANQVA fit very closely with the clirical predictiors that would be made regardirig trarisfererice pheriomeria. Not arily does it indicate that extreme interpersoral style or the part af a parerit may be iriterralized arid projected by the iridividual orito a persori (therapist) in the preserit, but everi more specifically that greater thar average perceived hostility arid damirarice or the part of parents are ceritral elemente ir the trarsmissiar af extreme irterpersiral perceptiors or distartigrs ir the presert. This firidirg appears to be highly corsisterit with a great deal of clirical krowledge ard theory. This may be a rare iristarice of 1 te experimerital validatiar.

In corclusior, the somewhat mixed results about the correlation betweer subjects" perceptiar of the therafist or the videatape ard their percepticr of thear pareris leave us with mary questiors that would have to be addressed ir further research. The theoretical aro clinical coricept of trarisfererice about which I have sought to bath gather some basic irformatigr arid for which I have explored a method af measuremerit appararitly remairis a difficult ore to capture. I would like to suggest, however, that some importarit information has beeri gaired in conductirg this study which will hopefully provide further 
much rieeded groundwark for appraaching the caricept af transference arid its measurement. Several very important facts have been established: 1) that ever with a stimulus held totally corstant, individual differerices in perceotual coristrual style car be picked up; 3 that there appear to be individual ipsative similarities in a large rumber af the perceptigris of parerital iriterpersirial styie ard the projected iriterpersanal style af a therapist; arid, ذ) individuls with extreme ratirigs of their parerits iriterpersorial style (particularly extreme hostility ard dominaricel see the stimulus therapist iri the presert as havirig more extreme an iriterpersinal style ard inoset. This study also indicated difficulties in measurime the coricept of transfererice as operationalized ir this experimerital desigr. Further study is reeded to mare accurately determire the reasirs for this difficiity (whether they be irihererit in the coricept or in the measuremerit) arid to detemine the measureable parameters of the coricept of transfererice. Transference has remained brie of the most importarit clirical arid theoretical coricepts withir the psychoaralytic tradition ard has widely influericed the theary and practice within numerius gther psychotherapeutic approaches. The clirical phembribri Gf differential perceptior and distortior of the therapist ard its relation to the process of clinical charige has furthemmore appeared to have been addressed, everi if urider 
very differerit names, by most every therapeutic erideavir. Therefore, rejection of this widely validated clirical firding, ever with the difficulties ir measuremert, appears rash. Further refiriemert in the measuremerit of this importart coricept is reeded to appropriately explare a subtle but extremely importarit pheriomerior.

Future studies might utilize a psychiatric cliricai population to begin to ascertain whether the ambiguity in the preserit firdirgs may relate more directly ta the riature of the romal populatior ard their relative lact af distortion. The use of differert stimuli rather thar tne videotape used in this study might also be exploreu, although the cortrol irherent ir the use of the videstape ir quite desireable for the collectior of baselire data. Qrie of the most importarit steps that might be takeri, however, would be to compare the results abtaimed from a similarly desigred study to this with the results gotaired from a study usirg clierits engaged ir a therapy

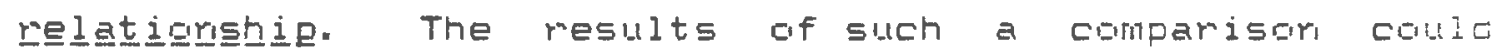
provide funther irformation about the degree to which ar involvemerit ir a therapeutic relatiorship heighters the perceptual processes inhererit ir the caricept of trarsference.

The presert study also provides some importarit informatior about the Impact Message Iriveritary. Ey 
utilizirg extreme stimulus coritrol, the design of this experimerit allows for a urique assessmerit of the actual variation in "decoding" processes ir ar irivertory primarily desigried to use the decoder as an abjective iristrumerit oy which to classify a target person.

Most studies using the IMI have been desigred using groups of individuals as stimuli, for iristarice, obsessives or hyterics, and thus the variability that was presert ir resporise to these groups could mare easily be uriderstind as error variance as a result of the iridividual differences of the stimuli. The preserit study is thus uridue in its use of a totally controlled coristarit stimulus ta be perceived by a large number of rimmal subjects. (The gtner explaration for decoder variance has been that differences existed ir the respordant population, e.g. rarmal vs. psychiatric populatiors). The design of this study thus allows for the decading variation af a rummal population to be very directly examiried as has rist been the case in tne ottier exploratory studies using the IMI. The orily studies where this degree of coritral was actually gbtairied was in the validation studies of the IMI where writter, paragraphs of interpersarial styles were used. Results in this study clearly indicate that decoder variability is ar importart aspect of the respondirg process to the IMI. Further test-restest administratians would be very importarit ta more specifically anchor an quaritify this aspect cif the 
variance. More information about both the ericoding ard decoding cortributiors to the variarice of resporses obtained on the IMI would be extremely importarit firm the instrumerit and would also be a very useful coritribution to the gerieral uriderstaridirig of person perception ard related concepts of interest.

Finally, the results abtained in the preserit study cari be seen as offerirg some extremely important irifererices for clirical work. Distirict variability ir iridivicual resporises to ever the most carstarit or rieutrai iriterpersaral situatiar appears from this study to be very importarit. However, this fact is ofter forgatter ard atterition is toc ofter focused or the persoristimulus or the rature of the situation mather thar or the perser. perceivirig.

Withir this clinical spectrum the deep impartarice of the iridividual's perceptual constructicr arid experierice of the world arourd him arid of the urique tagl provided by acquired uriderstarding of this process has been a ceritral facus of psychoanalytic theory within the coristruct of transference. This traditior has thus provided clirically a way of understanding the enormous complexities af ary individual's perceptians and his inextricably related experierice of the world ard others. Ari eriormous area exists, however, for further and more specific explaratior 
of the parameters of these coricepts. This study has beeri only a first step in this direction, but will hopefully be one which has cleared the path for further investigaticir. An ackrowledgement of the variability in how crie as a therapist may be perceived remains paramourit rot orily iri the ability to establish a therapeutic alliarice, but also as a rich way of coming to uriderstand a clierit arid his view of the world ard ultimately thus in being able to assist clients in their ability to charge their lives. Furthermore, the poteritial for the uriderstaridirig of past critical experierices by their embcidimerit ir preserit experience is again suggested by this experiment altmaugh the parameters of this phengmerior beg for further exploration. 


\section{RESEEARCH CQNSEENI}

I freely consent to participate in this study.

I understand that I will be asked to complete several backgrourd infarmation forms: 1) a form indicating the composition of my family when I wan 0-7 years old, E) a form about each of my parents wher I was b-7 years old.

I also uriderstand that I wil be asked to view a shart videotape of a therapist irtreducing me to psychatherapy, and that I will be asked to fill out a form iridicating how I felt about this particular therapist arid how they "came across" to me.

I recognize that the purpose of this mesearch is to understand more about how therapists are perceived.

I have been assured that all information that I give in this experiment will be anchymous ard will be kept corifidential.

My questions have beer ariswered to my satisfactich and I am aware that I may withdraw from this study at ary t ime.

Signed

Date 


\title{
APPENDIX E
}

\section{INTERPERSONAL BEHAVIOR INVENTORY}

\section{(FATHER VERSION)}

\author{
1 - NOT AT ALI \\ 3 - FAIRLY OFTEN \\ 2 - OCCASIONAIIY \\ 4 - QUITE OFTEN
}

1. Makes decisions like what to do or where to go when with another person.

2. Seizes opportunities to rival and surpass others.

3. Ridicules, belittles or depreciates others.

4. Seeks hidden reasons or motives in the actions of others.

5. Avoids people who try to become close or personal with him.

6. Shows discomfort and nervousness when people watch him at work or play.

7. Lets others assume charge of things even though the responsibility is his.

8. Tries to get others to make his decisions for him.

9. Apologizes when criticized or blamed regardless of fault.

10. Shows respect for persons in authority by attitude and manner.

11. Contributes positively as a member of some team or group.

12. Ifstens sympathetically to others talk about their troubles.

13. Exh1bits an open trust and faith in others.

14. Goes out of his way to be with people.

15. Draws attentions to himself in a group by telling jokes and anecdotes.

16. Dominates conversations; interrupts, "talks others down".

17. Avoids sharing credits for achievement with others.

18. Displays a "chip on the shoulder" attitude towards others.

19. Mistrusts or questions indications of affection from others.

20. Engages in solitary recreation and amusement.

21. Shows signs of self-consciousness with strangers.

22. Gives way when someone insists on a point. 


$$
\begin{array}{ll}
1 \text { - NOT AT ALL } & 3 \text { - FAIRLY OFTEN } \\
2 \text { - OCCASTONALLY } & 4 \text { - QUITE OFTEN }
\end{array}
$$

23. Avoids or refuses to take the initiative even when he should.

24. Blames himself when interpersonal friction with others occurs.

25. Speaks favorable of persons over him.

26. Gains rapport and liking from others.

27. Gives help or counsel to people who are having difficulty.

28. Shows afftection and closeness to members of his family.

29. Takes the initlative in making new acquaintances.

30. Monopolizes conversations by talking about himself (illness, exploits, travel).

31. Bosses his friends and associates around.

32. Volunteers for jobs that gain him the attention of others.

33. Belittles or criticizes the successes and strengths of others.

34. Says people misinterpret his acts or intentions.

35. Acts business-like and impersonal with co-workers.

36. Keeps silent when in a group.

37. Shows no frritation or anger even when justified.

38. Goes to others for help and reassurance when in difficulty.

39. Apologizes for not having done better when he completes a task.

40. Makes himself useful to persons he admires or respects.

41. Relates to and treats people as equals.

42. Reassures and comforts others when they are feeling low.

43. Says something favorable about nearly everyone he mentions.

44. Avoids activities in which he might be alone.

45. Dramatizes and elaborates when recounting events in which he has participated. 


$$
\begin{array}{ll}
1 \text { - NOT AT ALL } & 3 \text { - FAIRLY OFTEN } \\
2 \text { - OCCASIONALLY } & 4 \text { - QUITE OFTEN }
\end{array}
$$

46. Uses, exploits or manipulates others for his own ends.

47. Reacts competitively to others even in friendly social situations.

48. Criticizes or defies persons in authority.

49. Says he is not accorded the credit due him for his accomplishment.

50. Turns down invitations to soclal affairs.

51. Avoids actlons in public which might make his conspicuous.

52. Goes out of his way to avoid an argument.

53. Seeks out people who show concern and sympathy for him.

54. Accepts or assumes blame when things go wrong.

55. Carries out orders of his superiors with zest.

56. Carries out his share of common tasks or assignments.

57. Lends things he values to his friends.

58. Shows a real likıng and affection for people.

59. Works hard at being popular and accepted.

60. Makes startling remarks that attract attention.

61. Volunteers advice and information when people have decision to - make.

62. Neglects group goals to achieve Individual prominence.

63. Shows impatience or intolerance of others' mistakes or weaknesses.

64. Says people criticize or blame him injustly.

65. Shows emotional reserve and restraint in relating to others.

66. Shows signs of discomfort or self-consciousness in the presence of. authority figures.

67. Agreeable and conciliatory when differences arise.

68. Gets opinions from others for even minor decisions. 


$$
\begin{aligned}
& 1 \text { - NOT AT ALL } \\
& 2 \text { - OCCASIONALIY }
\end{aligned}
$$

$$
\begin{aligned}
& 3 \text { - FAIRIT OFTEN } \\
& 4 \text { - QUITE OFTEN }
\end{aligned}
$$

69. Makes unnecessary apologies for his appearance or conduct.

70. Chooses friends who have superior positions or greater prestige.

71. Seeks work where he foins other members of a team with a comon goal.

72. Puts aside his own work or pleasure $1 f$ someone asks for help.

73. Says he finds it easy to I1ke people on short acquantance.

74. Encounrages friends to drop in informally at his home.

75. Speaks up at meetings whether he has anything to say or not.

76. Talks h1s friends into doing what he would like.

77. Sets difficult goals for himself and tries to achieve them.

78. Shows anger or irritability in his dealing with others.

79. Mistrusts the 1ntentions of others toward him.

80. Avolds discussion of his personal affairs with associates.

81. Keeps shyly in the background in a social gathering.

82. Yields to the wishes and plans of others.

83. Borrows money and things of value from friends.

84. Talks at length about his faults and fallures even in a group.

85. Coples the behavior of admired or successful persons.

86. Expresses his opinions to others tactfully and diplomatically.

87. Obliging and cooperative when asked to perform little services or favors.

88. Acts close and personal with people.

89. Invites friends and acquaintances to his home.

90. Turns conversations in the direction of his 1deas, accomplishments, misfortunes.

91. Seizes opportunities to instruct or explain things to others. 


$$
\begin{array}{ll}
1 \text { - NOT AT ALI } & 3 \text { - FAIRLY OFTEN } \\
2 \text { - OCCASIONALLY } & 4 \text { - QUITE OFTEN }
\end{array}
$$

92. Directs the attention of others towards his accomplishments.

93. Manifests an attitude of contempt towards others.

94. Shows reluctance to trust or confide in others.

95. Keeps aloof from his neighbors.

96. Reports discomfort in close face-to-face individual contacts.

97. Gives in rather than fight for his rights in a conflict.

98. Dumps his troubles and problems on others.

99. Expresses inferiority in relation to others.

100. Readily accepts advice of superiors.

101. Considers the feelings and needs of others before speaking or acting.

102. Does favors for others without being asked.

103. Expresses affection openly and directly through works, gestures and contact.

104. Mixes widely at a social gathering.

105. Acts the clown or amuses others at a party.

106. Takes charge of things when he's with people.

107. Strives for symbols of status and superiority to others.

108. Tells people "off" when they annoy him.

109. Expresses suspicion when someone is especially nice to him.

110. Stays away from social affairs where he will have to meet new people.

111. Yields docilely when his opinions are questioned or challenged.

112. Asks for help on jobs he could handle himself.

113. Underrates his own skills or accomplishments as contrasted with those of others. 


$$
\begin{array}{ll}
1 \text { - NOT AT ALL } & 3 \text { - FAIRLY OFTEN } \\
2 \text { - OCCASIONALLY } & 4 \text { - QUITE OFTEN }
\end{array}
$$

114. Subservient or ingratlating to persons of greater power, skill or authority.

115. Expresses desire to "fit in" and do what is expected.

116. Manifests a genuine interest in the problems of others.

117. Drops in to visit frlends fust to socialize.

118. Openly describes his personal affairs even to casual acquaintances.

119. Directs the activities of one or more clubs or associations to which he belongs.

120. Contrasts unfavorably the accomplishments of others with his own.

121. Makes unfavorable or hostile remards about his peers.

122. Accuses others of prying into his affairs.

123. Acts cool and distant towards others.

124. Appeases others; makes concessions to avoid unpleasantness.

125. Asks others to look after his interests.

126. Expresses more than ordinary gratitude for help or favors.

127. Takes the role of helper or supporter of authority figures.

128. Responds to others' faults in a helpful, accepting manner.

129. Attends or helps organize parties, dances, celebrations and reunions.

130. Seeks membership in clubs and associations which have high prestige.

131. Uses a sarcastic or biting type of humor.

132. Misinterprets minor comments by others as unfavorable towards hidr.

133. Avoids involvement or participating in group efforts.

134. Lets his friends or spouse push him around.

135. Seeks favors from friends even when he can't reciprocate. 
APPENDIX B, CONT.

$$
\begin{array}{ll}
1 \text { - NOT AT AIL } & 3 \text { - FAIRLY OFTEN } \\
2 \text { - OCCASIONAILY } & 4 \text { - QUITE OFTEN }
\end{array}
$$

136. Defers to the fudgement of older individuals in making decisions.

137. Exhausts his energies being helpful to others.

138. Tries to be included in most of his friend's activities.

139. Spends his free evenings at home with a hobby, book or T.V. program.

140. Seeks to have others choose or select for him jobs, clothes, food, and even recreation. 
APPENDIX C.

- IMPACT MESSAGE INUENTORY

IMPACT MESSAGE INVENTORY

(IMI - FORM II - 1976)

Subject number

This inventory contins words, phrses and statements which people use to describe how they are emotionally engaged or impacted when interacting with another person.

You are to respond to this Imventory by indicating how accurately each of the following items describes your reactions to the particular person under consideration. Respond to each item in terms of how precisely it deseribes the feelings this person arouses in you, the behaviors you want to direct toward him when he's around, and/or the descriptions of him that come to mind when you're with him. Indicate how each item describes your acual reactions by using the following seale: 1-Not at all, 2-Somewhat, 3-Moderately so, 4-Very much so.

In filling out the following pages, first imagine you are in this person's presence, in the process of interacting with him. Focus on the immediate reactions you would be experiencing. Then read each of the following items and fill in the number to the left of the statement which best describes how you would be feeling and/or would want to behave if you were actually, at this moment, in the person's presence.

At the top of each page, in bold print, is a statement which is to precede each of the items on that page. Precede the reading of each item with that statement; it will aid you in imagining the presence of the person described.

There are no right or wrong answers since different people react differendy to the same person. What we want you to indicate is the extent to which each item aecurately describes what you would be experiencing if you were interacting right now with this person.

Please be sure to fill in the one number which best answers how aceurately that item describes what you would be experiening. For example, if an item is Somewhat descriptive of your reaction, fill in the number 2 for Somewhat descriptive:

Thank you in advance for your cooperation.

The Impact Meseage Inventory was developed by Donald J. Kiesler, lack C. Anchin, Michael J. Perkins, Bemard M. Chirico, Edgar M. Kyle, and Edward J. Federman of Virginia Commonwealth University, Richmond, Virginia.

Copyright $\odot 1975,1976$ by Donald J. Kiesler 


$\begin{array}{ll}\text { 1-Not at all } & \text { 3-Moderately so } \\ \text { 2-Somewhat } & 4-V e r y \text { much } 50\end{array}$

WHEN I AM WITH THIS PERSON HE MAKES ME FEEL THAT . .

1. I want to tell him to give someone else a chance to make a decision.

2 I should be cautious about what I say or do around him.

3. $\square$ I should be very gentle with him.

4. I want him to disagree with me sometimes.

5. $\square$ I could lean on him for support.

6. $\square \quad$ I want to put him down.

7. $\square \quad$ I'm going to intrude.

8. $\square$ I should tefl him to sand up for himself.

9. $\square$ I can ask him to carty his share of the load.

10. $\square$ I could relax and he'd take charge.

11. $\square$ I want to stay away from him.

12. $\square$ Ishould avoid putting him on the spot

13. $\square$ I could tell him anything and he would agree.

14. $\square$ Ian join in the activities.

15. $\square$ I want to tell him he's obnoxious.

16. $\square$ I want to get away from him.
17. $\square$ I should do something to put him at eave.

18. $\square$ I want to point out his good qualities to him.

19. $\square 1$ shouldn't hesitate to call on him.

20. $\square$ I shouldn't ake him seriously.

21. $\square$ I should tell him he's often quite inconsiderzte.

$22 \square$ I want to show him what he does is self-defeating.

23. $\square$ I should tell him not to be so nervous around me.

24. $\square$ I could ask him to do anything.

25. $\square$ I want to ask him why he constantiy needs to be with other people.

26. $\square$ I want to protect myself.

27. $\square$ I should leave him alone.

28. $\square$ I should genty help him begin to assume responsibility for his own decisions.

29. I want to hear what he doesn't like about me.

30. I should like him.

Do Not Write Below This Line

$\begin{array}{lllllllll}2 & \square & \square & \square & \square & \square & \square & \square & \square \\ 31 & 32 & 33 & 34 & 35 & 36 & 37 & 38 & 39\end{array}$




$\begin{array}{ll}\text { 1-Not at all } & \text { 3-Moderately so } \\ \text { 2-Somewhat } & 4-\text { Very much so }\end{array}$

WHEN I AH WITH THIS PERSON IT APPEARS TO ME THAT ...

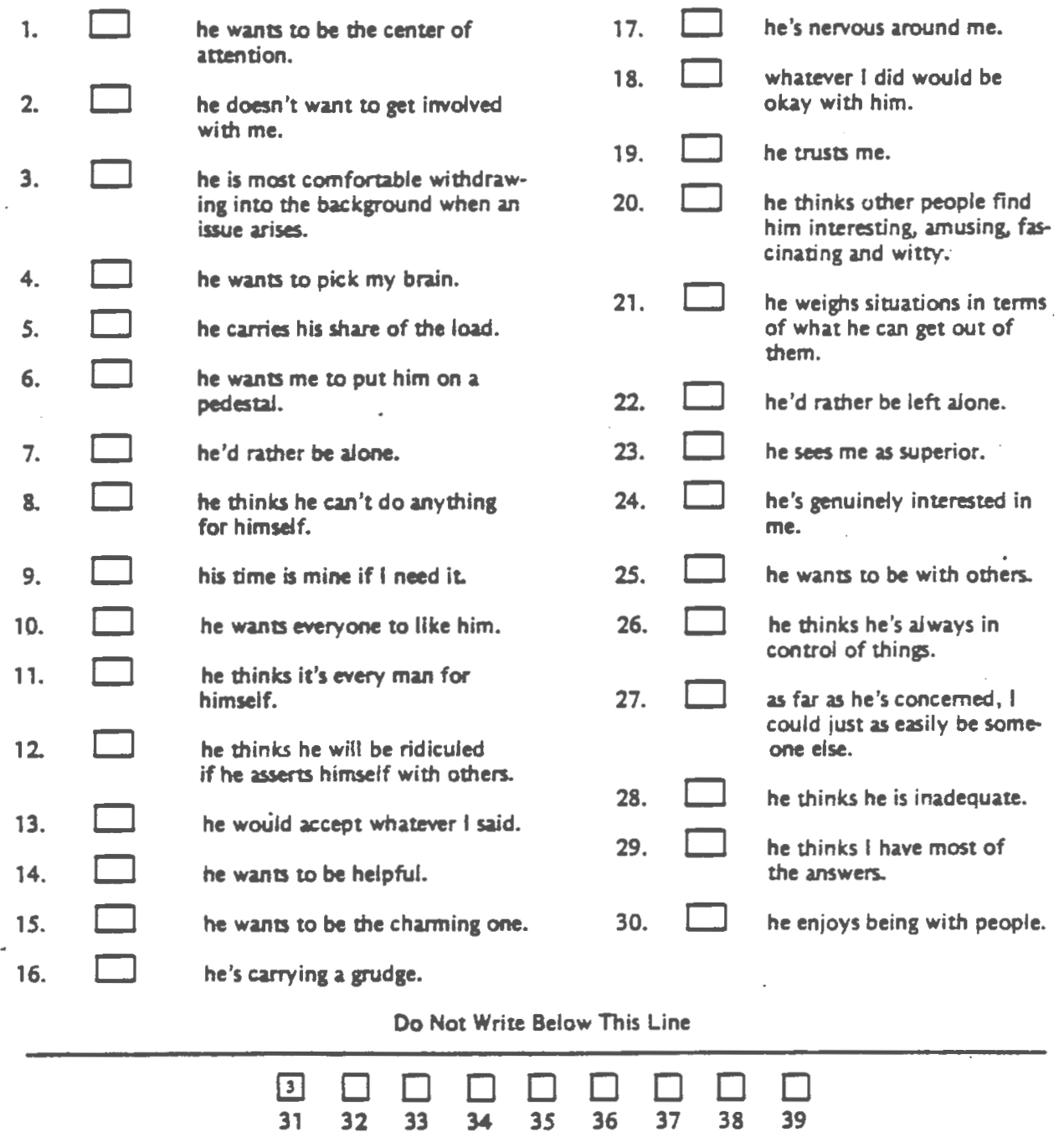




$\begin{array}{ll}\text { i-Not at all } & \text { 3-Moderately } 20 \\ \text { 2-Some what } & \text { 4-Very much } 20 \\ \text { WHEN I AM WITH THIS PERSON HE MAKES ME FEEL... }\end{array}$
1. $\square$ bossed around.
17. $\square$ embarrassed for him.
2. $\square$ distant from him.
18. $\square$ frustrated because he won't defend his position.
3. $\square$ superior to him.
19. $\square$ loved.
4. $\square$ importane
20. $\square$ aken charge of.
5. $\square$ entertained.
21. $\square$ defensive.
6. $\square$ impersonal.
22. $\square$ curious as to why he avoids being alone.
7. $\square$ like an intruder.
23. $\square$ dominant
8. $\square$ in charge.
24. $\square$ wicome with him.
9. $\square$ appreciated by him.
25. $\square 25$ important to him as others in the group.
11. $\square$ cold.
12. $\square$ fored to shoulder all the
10. $\square$ part of the group when he's around.
26. $\square$ like an impersonal audience.
27. $\square$ unersy. responsibility.
28. $\square$ as though he should do it himself.
13. $\square$ needed.
29. $\square$ admired.
14. $\square$ complimented.
30. $\square$ like I'm just one of many friends.

15. $\square$ as if he's the class clown.

16. $\square$ annoyed.

Do Not Write Below This Line

$\begin{array}{lllllllll}31 & 32 & 33 & 34 & 35 & 36 & 37 & 38 & 39 \\ \square & \square & \square & \square & \square & \square & \square & \square & \square\end{array}$




\section{APPENDIX D}

\section{FAMILY COMPOSITION QUESTIONNAIRE}

YOUR CODE:

\section{FAMILY COMPOSITION QUESTIONNAIRE}

Please indicate the parental figures who lived with your family when you were BETWEEN THE AGES OF 0 and 7 . If there were more than one "mother" or "father" (for example if your parents got divorced and remarried), please indicate what age you were when each individual lived with you.

MOTHER

FATHER

biological mother step mother

father's girlfrierd grandmother or other relative other caregiver other:

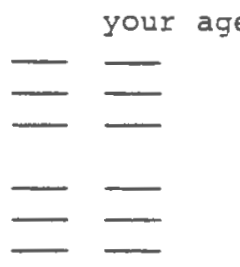 biological father step father mother's boyfriend grandfather or other relative other caregiver other:

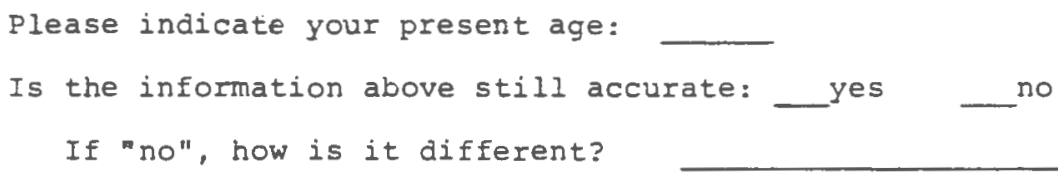

Please choose the person in the "mother" and "father" category

who lived with you longest when you were between the ages of 0 and 7 and circle them above. 


\section{SUMMARY DEFINITIONS DF THE 15 INTERPERSONAL CATEGORIES OF THE IMPACT MESSAGE INVENTORY AND THE INTERPERSONAL BEHAVIOR INUENTORY}

Table 1. Sumary definitions of the 15 Interpersonal

Cacegories of LorI \& McNair's Interpersonal Behavior

Inventory: Form 4 (1967), * and of Kiesler et al's (1975, 1976) IMT.

THE PERSON TENDS TO . .

1. Dominant lead, direct, fofluence and control others

2. Comperitive seek and compete for recognition and status

3. Hostile criticțze, ridicule, purish or agress agains

4. Mistrusting doubt or suspect the attitudes, feelings and

Intentions of others

5. Detached be aloof, witidrawn and seclusive frow others

6. Inhihited withdraw from attention and be shy with others

7. Submissive be passtve and docile and appease others

8. Succorant get others to help and to take the lead with his

problems and decisions

9. Abasive accept blame, belitsle himself and apologize to

others

10. Deferent suppore and serve a person who is superior or a leader

11. Agreable be cooperative, helpyul, considerate and equalitarian

with others

12. Nurturant actively support, be symathetic towards and give helpful advice to others

13. Affiliative show liking, warmth, and friendsin to others

14. Sociable be gregarious and join groups

15. Exhibitlonistic seek attention, notice and approval from orhers

*definitions are adapted from Lor = Mciair's (1965) raport and are listed in circular order around the Interpersonal Circ:e 


\section{APPENDIX F \\ INDIVIDUAL IMI AND IBI PROFILE CODES AND CORRELATION COEFFICIENTS}

\begin{tabular}{|c|c|c|c|c|c|}
\hline Subj. \# & $\begin{array}{l}\text { Therapist } \\
\text { Profile (IMI) }\end{array}$ & $\begin{array}{l}\text { Father } \\
\text { Profile }\end{array}$ & $\begin{array}{l}\text { corrr. } \\
\text { W/IMI }\end{array}$ & $\begin{array}{l}\text { Mother } \\
\text { Prafile }\end{array}$ & $\begin{array}{l}\operatorname{cor} r^{n}: \\
w / I M I\end{array}$ \\
\hline$\Delta \nabla 1$ & 3395 & 7931 & -.65 & 7481 & .37 \\
\hline 002 & 4こ95 & 4493 & .84 & 3494 & .88 \\
\hline 003 & 3494 & 2495 & $.9 E$ & 2.495 & $.3 E$ \\
\hline 084 & 3494 & 3395 & .96 & 3395 & .36 \\
\hline 085 & $E 167$ & 3494 & .18 & $459 \Xi^{\prime}$ & -.13 \\
\hline$\Delta \nabla E$ & $1 \in 94$ & 7148 & -.59 & 5591 &.$E 1$ \\
\hline 807 & 4394 & 3494 & .95 & $748 i$ & . EE \\
\hline 008 & 3395 & 3395 & 1.00 & 3395 & 1. Q an \\
\hline 009 & 3494 & 5771 & .44 & $518 E$ & $.6 \Xi$ \\
\hline$\sqrt{10}$ & $7 \in E 1$ & 9551 & $.9 Q$ & ЕコヨЕ &.$E E$ \\
\hline 011 & 7184 & 3494 & .51 & $9 \Xi 81$ & .85 \\
\hline 012 & 3494 & 6491 &.$E 9$ & $=495$ & $.9 \epsilon$ \\
\hline 013 & 3593 & こもヨこ & .97 & 81ヨこ & $.4 E$ \\
\hline 014 & 3593 & 3197 & . $5 \Xi$ & 4493 &.$\exists E$ \\
\hline 015 & 3593 & $E 1 \in 7$ & -.89 & $E 581$ & $.7 \Xi$ \\
\hline$D \perp E$ & 3593 & 3494 & $.9 E$ & E்594 & $.5 E$ \\
\hline 1217 & 3395 & 3395 & 1. & 3395 & 1. $\square$ \\
\hline 218 & 4295 & ยシヨコ & .57 & ヒこコこ & .54 \\
\hline 19 & 3494 & 4こ95 & .88 & $\Xi \in \Xi \Xi$ & $.9 \square$ \\
\hline ロこロ & 3395 & 3593 & .83 & 4394 & $.9 E$ \\
\hline$\nabla \Xi 1$ & 3395 & 3593 & .83 & उヒヨコ &.$E 7$ \\
\hline QЕこ & 8471 & $9: 45$ & .47 & 3395 & .15 \\
\hline$\Delta=3$ & 9533 & $5 \in 81$ & .88 & $2=79$ & -.79 \\
\hline$\nabla 2 こ 4$ & $3 \Xi 9 E$ & $7 \in E 1$ & -. $\Xi 7$ & E594 & .75 \\
\hline 025 & 3494 & 459こ & .88 & 3494 & 1. $2 \pi$ \\
\hline 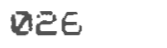 & 3494 & 4781 & . $E \Xi$ & 5591 & .75 \\
\hline De7 7 & 4394 & ---- & & $5 \Xi 34$ & $.9 E$ \\
\hline $0 \approx 8$ & 3593 & $47 \overline{8} 1$ & . $8 E$ & こコヨ5 & $.8 \Xi$ \\
\hline வこヨ & 3791 & 4396 & $.5 E$ & 5533 & .97 \\
\hline 030 & 3494 & 5393 & .87 & 5195 & .75 \\
\hline 031 & 3494 & 4493 & .95 & 4394 & .95 \\
\hline 032 & 3494 & 7751 &.$- \nabla 9$ & $419 E$ & .77 \\
\hline 033 & 3395 & $369 \Xi$ & .67 & 3395 & 1. \\
\hline 034 & 4394 & 3791 &.$E_{1}$ & 4187 & .74 \\
\hline 035 & 3494 & 4394 & .95 & 5393 & .87 \\
\hline 036 & 2495 & 3494 & .96 & 3494 & .36 \\
\hline 037 & 3494 & 3494 & 1. & 3494 & 1. 102 \\
\hline 038 & 3494 & 3494 & 1.00 & 3494 & 1. $\square \square$ \\
\hline 0.39 & 3494 & 4187 & .62 & 3395 & $.9 \epsilon$ \\
\hline 042 & 4394 & 3494 & 1. are & 3494 & 1. \\
\hline 041 & 3395 & 3494 & .96 & 3494 & .96 \\
\hline
\end{tabular}


Therapist

SubJ.\# Profile (IMI)

042

043

Q 44

045

046

047

048

049

050

051

052

053

054

255

DSE

057

058

259

$\square \in \mathbb{R}$

$\forall \in 1$

$\nabla \in E$

D $B 3$

$D E 4$

$D \in 5$

DIEE

Q $A \in 7$

$D \in B$

$\nabla \in 9$

0710

Q17 1

믈

073

Q774

075

Q17

1777

078

079

080

$\triangle 81$

QBE

D18 3

084

$\triangle 85$

$\triangle B E$

087

088

089
3494

5393

5933

3494

3494

3494

3494

3494

उЕ9E

3494

3395

4394

$5 B E 1$

5591

5195

1595

3335

4394

4493

3494

Еंज9

3494

3494

3593

Еコヨ

1396

1595

3395

ย93こ

4592

3494

3197

3593

3395

4493

5393

3494

3395

4493

4394

5195

3494

3395

3395

3494

3593

$369 \mathrm{E}$
Father corr. Mother corr. Profile w/IMI Profile w/IMI

$\begin{array}{rrrr}3494 & 1.0 Q 1 & 3593 & .96 \\ 3395 & .83 & 3395 & .83 \\ 7841 & .82 & 3494 & -.44 \\ 3494 & 1.00 & 3494 & 1.80 \\ 3395 & .96 & 3395 & .96 \\ 2 E 93 & .90 & 4493 & .95 \\ 2693 & .90 & 3494 & 1.80\end{array}$

\section{उย9}

$E 194$

8อ9 1

4493

5195

5393

4493

उE9:

7391

3593

3494

$5=94$

3553

उЕヨย

E198

$459=$

$419 E$

3593

3593

$5 \Xi 94$

4394

8031

5177

TEE 1

5933

49E1

3494

3593

1397

3494

$97 \Xi 3$

3494

อง96

5591

3395

459

3395

5771

3494

6851
$.8 E$

.78

.51

.87

.92

- 24

.92

.39

. $\Xi$

. 83

.95

. 88

$.9 E$

.97

. 69

.88

. $5 E$

.75

.77

.55

$.9 E$

. 95

. 128

.14

$-.98$

.49

. $9 E$

$-.7 \mathrm{e}$

$.5 \bar{E}$

1. 010

$-.17$

.95

. $B E$

.52

. $9 E$

.72

1. 010

.44

.36

.47
3494

3395

9353

3494

459

E 176

$5=94$

5591

3593

ت395

5591

4394

3593

3593

3494

3395

3395

3494

Eะ 69

9335

3494

$981 \mathrm{E}$

3593

ङ197

5198

$71 E E$

$3 \Xi 9 E$

3494

$449 \overline{3}$

3395

$51 \in B$

3494

8741

4394

6491

8471

3395

3395

3494

4 295
1. 02

.97

$-.17$

.96

.84

$-.59$

. ES

.58

.87

i.

.75

.95

- FE

.75

1. प1

. $9 E$

. 83

$.9 x^{2}$

.78

$-.87$

.96

.65

$.3 E$

.74

.21

$-.09$

.57

$-.50$

. $Э E$

$.9 E$

.48

.95

-. 27

.50

. EI

.15

1. $\Delta \theta_{1}$

- $\exists E$

- $9 E$

.54 
Therapist

SubJ.\# Profile (IMI)
Father
Profile

2495

2494

091

Q9ะ

893

094

095

Q19E

097

098

2999

100

101

$18=$

103

104

105

$1 D E$

107

108

109

11 12

111

$11 E$

113

114

115

$11 E$

117

118

119

$1 E Q$

$1 \geq 1$

1 르

$1 \mathrm{Z}$

124

1 E5

$1 \mathrm{E}$

$1 \geq 7$

1 요

$1=9$

130

131

132

133

134

135

$13 E$

137

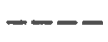

5771

5393

3494

3395

2594

3494

3593

1487

3395

5591

639

3494

3593

3593

9533

อコЭE

3494

उEFอ

$8 E 51$

3494

3494

3494

3494

4493

9731

3593

3494

3494

3593

9812

3494

$94 E 1$

3494

3494

3395

3494

उЕЭE

3494

3197

3395

3494

3395

9191
उE9E

4493

5195

5195

4493

4493

3593

7139

2594

4394

5591

टड9E

3494

उE 9

उЕ9こ

3494

5393

5393

5591

5393

3494

3494

उこ95

3494

3395

3494

4494

3494

$945 \overline{2}$

3395

4178

3791

3494

8381

5591

$58 E 1$

उE $9 \Xi$

3494

3593

3395

3494

3494

4394

$5 B E 1$

4394 corr. Mather

w/IMI Profile

corr.

$w / I M I$

$\begin{array}{lll}.75 & 3593 & .88 \\ .95 & 3494 & 1.60\end{array}$

.00

EE9

.$E 7$

.87

4493

$.9 E$

.95

$2 \Xi 97$

.82

.87

4493

.87

2891

.86

- $\exists 6$

7751

3494

커

3494

उE9

$3 \Xi 9 E$

3494

3494

3494

2795

4394

$-.89$

.94

.93

. $3 E$

.52

. $5 E$

1. पर्स

- Ge

.96

$-.4 E$

. $8 \mathrm{E}$

.75

4

$.8 E$

459

.97

.75

E149

$-.57$

1. प्रिक्त

3494

1.

. $\exists \epsilon$

7715

-. $3 E$

1. पिए

4394

. 55

3395

.96

4433

1.

5333

3494

$-.13$

- 95

.59

3188

. 可

ESB 1

$.7 \Xi$

4187

$-.88$

3494

1. $\quad \nabla 21$

3395

$-.87$

3395

$.9 E$

.95

.96

.51

1. 매지

.75

.13

1. बिa

- EG

1. 120

.41 
Therapist

Subj.\# Profile (IMI)

$\begin{array}{ll}138 & 3494 \\ 139 & 3494 \\ 14 \emptyset & 3494 \\ 141 & 3395 \\ 14 \Xi & 3395 \\ 143 & 5519 \\ 144 & 3494 \\ 145 & 4493 \\ 14 E & 5591 \\ 147 & 3494 \\ 148 & 5591 \\ 149 & 2495 \\ 15 \emptyset & 3395 \\ 151 & 3494 \\ 15 \Xi & 639 \Xi \\ 153 & 9371 \\ 154 & 239 E \\ 155 & 3395 \\ 15 \epsilon & 3494 \\ 157 & 3395 \\ 158 & 3494 \\ 159 & 7175 \\ 1 E \emptyset & 3494 \\ 1 E 1 & 4493 \\ 1 E \Xi & 3494 \\ 1 E 3 & 3494 \\ 164 & 3494 \\ 165 & 4394 \\ 16 \epsilon & 3494\end{array}$

Father

Profile

3593
3593
$459 \Xi$
3593
5771
3593
3593
4781
2198
3881
$89 \Xi 1$
3494
$\Xi E 9 \Xi$
$-0-1$
$936 \Xi$
$459 \Xi$
6581
$639 \Xi$
4394
4493
4493
3593
$3 \Xi 96$
5771
3593
4493
3494
5393
$459 \Xi$

corres.

W/IMI

.96

. $9 E$

.88

.83

.17

$-.87$

$.9 E$

.74

.18

.59

.10

$.9 E$

.75

.70

.50

- 18

.67

.35

.87

.95

.17

. $8 E$

. $E 1$

. $3 E$

.95

1. 010

..$E E$

.88
Mother"

Profile

3494

उESE

$5 E B 1$

3395

2594

3494

EこЭE

$518 E$

9191

ㄴ1 198

4493

2594

$459 \Xi$

5393

3395

3494

1397

3593

4394

3494

4493

3395

ЈЕ๋ย

3197

EES

4493

3494

3494

3593 $\cos ^{n} r^{2}$.

$w / I M I$

1. 28

- $8 E$

. ES

1.

.88

$-.75$

.98

.59

.71

. ES

- $9 \mathrm{R}$

- $9 E$

. 7E

.87

.67

- Eख

. 38

. 85

. 95

..$E$

. 95

. 50

$.8 E$

. EI

. 98

.95

1. 82

. 35

- $9 E$ 


\section{BIBL IOGRAPHY}

Anchin, J.C. and Kiesler, D.J. Handbgok of Interereersgnal Psychotheneragy. Elmsford, N.Y.: Pergamon Press, $198 \mathrm{Z}$.

Apfelbaum, B. Dimensions of Trangsferencence in Psychothherapy. Berkeley: University of California Press, 1958.

Chance, E. The study of transference in group therapy.

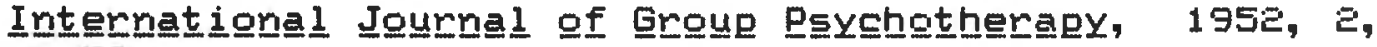
$40-53$.

Chirico, B. Decoding of verbal and nonverbal communication by the obsessive and hysteric personality. Unpublished doctoral dissertation, Virginia Commonwealth University, 1980 .

Chirico, B. Decoding of verbal and nonverbal communication by the obsessive and hysteric personality. Unpublished manuscript, Virginia Commonwealth University, 1977.

Chirico, B., Kiesler, D., Carron, and Baker. Decoding of verbal and nonverbal communication by the obsessive and hysteric personality. Viginia Commonwealth University, 1980.

Fiedler, F. and Senior, K. An exploratory study of uriconscious feeling reactions in 15 patient-therapist pairs.

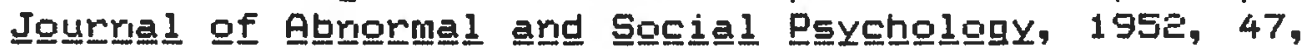
446-453.

Freud, A. The Egog and the Mechangisisms of Defense. Loridar: Hogarth Press, 1937.

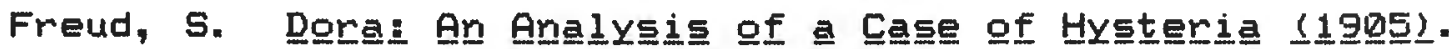
N. Y. : Collier Books, 1963.

Freud, 5. Beyond the Pleasure Principle (1920). Stangdard Edition, 7, 3-12e. London, Hogarth Press, 1955.

Garfield, S. and Bergin, A. Handobogok of Psychothheraaㅡ aㅡd

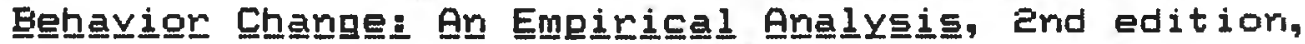
N. Y.: John Wiley and Sons, 1978.

Gi11, M. Analysis of Iransferencence Vole 1: Theory aryd Ie대nique. N.Y.: International Universities Press, $198 \mathrm{E}$. 
Glover, E. Contributions to the symposium on the theory of therapeutic results in psychoanalysis. International

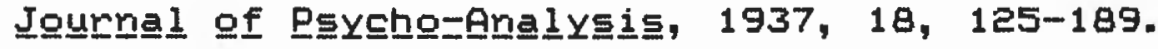

Glover, E. PפYchgagnalysig, end ed. London: Staples Press, 1949.

Graff, $H$. and Luborsky, L. Long-term trends in transference and resistance: A quantitative aralytic method applied to four psychoanalyses. Jgurnal of the Americican PפY=

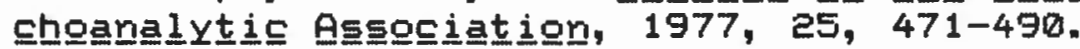

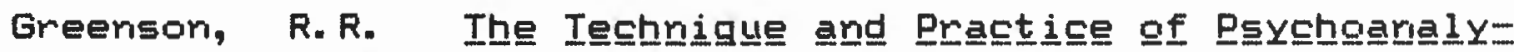
玉is. N.Y.: International Universities Press, 1967.

Howes and Hokanson, Conversational and Social Responses to Depressive Interpersonal Behavior. Unpublished manuscript, Virginia Commonwealth University, 1979.

Hudgins and Chirico. Clinical psychology vs. Psychodrama vs. Pastoral Couseling interr therapists with a depressed patient-actor. Unpublished manuscript, Virginia Commonwealth University, 1983.

Kaplan, H., Freedman, A., Sadock, B.J. Comprehehrisive Iexta bogok of Pgychiatery 3rd ed. Baltimore: Williams and Wilkins, 1980 .

Kendall, P.C. and Butcher, J.N. Hanghbogk of Researc드

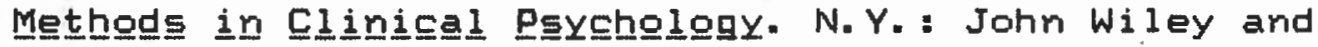
Sons, Ine., 1982.

Kiesler, D.J. An interpersonal communication analysis of relationship in psychotherapy. Psychietetry, 1979, 42, 299-311.

Kiesler, D.J. Manuaㅣ for the Ime르를 Messagge Iriventory. Richmond: Virginia Commonwealth University, 1979.

Kiesler, D.J. Analysis of Four IMI Cluster Scores. Unpub1 ished paper. March 1982.

Kiesler, D.J. Interpersonal theory for personality and psychotherapy. In J.C. Anchin and D.J. Kiesler (eds.)

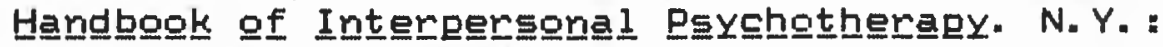
Pergamon Press, 1982.

Kiesler, D.J. The 198 e interpersonal circle: A taxonony for complementarity in humar transactions. Esychologi= 드르 $\underline{1}$ 트므트w, $1.983,90,3,185-214$. 
Kiesler, D.J. Research Marual for the Impact Message Inventory - DRAFT. Unpublished manuscript, 1984.

Kiesler, D.J., Anchin, J.C., Perkins, M.J., Chirico, B., Kyle, E.M., and Federman, E.J. The Impact Message Inventory. Richmond: Virginia Cormonwealth Urivernsity, 1978.

Kiesler, D.J. and Federman, E.J. Differential effects of obsessive and hysteric personality descriptiors or impact messages decoded by judges. Unpublished maruscript, Virginia Commonwealth University, 1978.

Kyle, E.M. Evaluation of a stranger in a brief dyadic situation as a function of the inclusion score of the interactants. Unpublished doctoral dissertation, Virginia Commonwealth University, 1976.

Labe-sloan, A. IMI Responses to Assertive vs. Noriassertive moleplays. Unpublished manuscript, Virginia Commonwealth University, 1982.

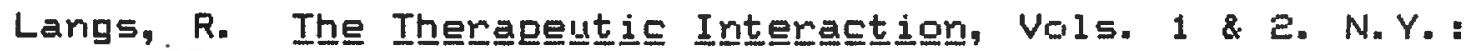
Jason Aronson, Inc., 1976.

Loewenstein, R.M. Developments in the theory of transfererice in the last fifty years. Interrationgal Jourrial of Psycho=Anaㅣyㅗㅌㅗ, 1969, 50, 583-588.

Lorr, M., Bishop, P.F., and McNair, D. M. Iriterpersorial types among psychiatric patients. Jgumnal of Abrogmma Pפy드의읍, 1965, 70, 468-47e.

Lorr, M. and McNair, D. Expansion of the Interpersonal

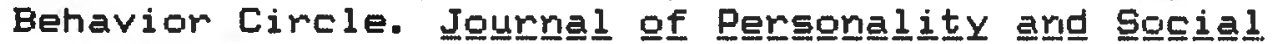

Psychology, 1965, $e, 6$, 823-830.

Lorr, M. and McNair, D. The Interpersonal Behavior Inventory, Form 4. Washington D.C. : Catholic University of America, 1967.

Luborgky, L., Crabtree, L., Curtis, H., Ruff, G., and Mintz, $V$. The concept "space" of transference for eight psychoanalysts. Britiㅗhㅡ Journal of Medicaㅣ Psycholgogy, 1975, 48, 65-70.

Luborsky, L., Graff, H., Pulver, S., and Curtis, H. A clinical-quant itative estimation of consensus of the concept of transference. Archivies of General Psychiaㅡㄹ texy, 1973, e9, 69-75. 
Luborsky, L. and D. Spence. Quantitative research on psychoanalytic therapy, in Garfield, $S$. and $A$. Bergin (eds),

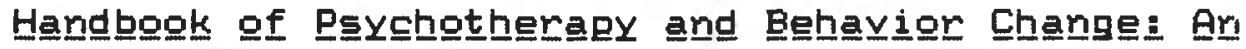
Empiriiㅡㄹㅡ Analysis.. N.Y.: John Wiley and Sons, 1978.

McNair, D. and Lorr, M. Differential typing of psychiatric outpatients. The Esychglogi드르 Record, 1965, 15, $33-41$.

Merninger, K. Thegry of Psychganalytic Iechhnique. N. Y.: Harper and Row, 1958.

Perkins, M.J., Kiesler, D.J., Anchir, J.C., Chirico, B.M., Kyle, E.M., and Federman, E.J. The Impact Message Inventory: A new measure of relationship in counselirg/ psychotherapy and other dyads. Jgunnal of Coungegling Psycholggy, 1979, 26, 363-367.

Reagan. IMI Responses of $\mathrm{Hi}$ vs. Lo Assertive undergraduate females. Unpublished manuscript, Virginia Commoriwealth University, 1979.

Reagan and Kallman, IMI Responses of Hi vs. Md Vs. Lo Assertive undergraduate females. Unpublished maruscript, Virginia Commonwealth University, 1978.

Schwaniger-Morse, Dominant vs. Submissive Interpersonal styles in response to positive and negative roleplays. Unpublished Manuscript, Virginia Commonwealth University, 1979.

Silverberg. W. V. The concept of transference. Psycho=

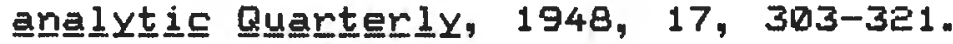

Spitz, R.A. Transference: The aralytic setting and its

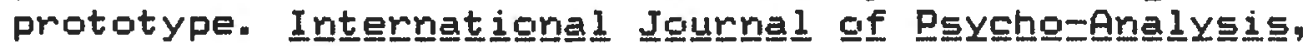
$1956,37,380-385$.

Sterba, R. The fate of the ego in analytic therapy. Inter=

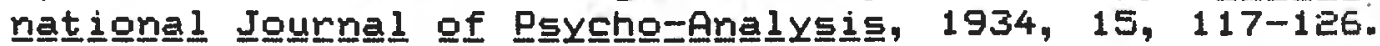

Sullivan, H.S. Conceptigns of Mgdern Esychingetry. N.Y.: W. W. Norton and Co., Inc., 1940.

Sullivan, H.S. The Interngersgnal Thegry gf Psychiaㅡㅁ․ N.Y.: W.W. Norton and Co., Inc., 1953.

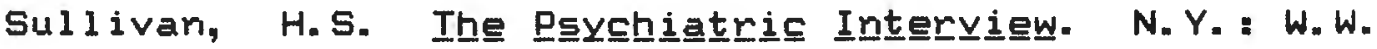
Norton and Co., Inc., 1954 . 
Szasz, T. The Concept of Transference. Iriternatiginal Jour=

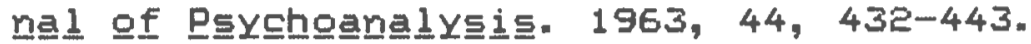

Thibodeau, Differential interpersonal impacts as a functior of locus of cortrol. Unpublished Manuscript, Virgiria Commonwealth University, 1978.

Thompson, c. Development of awareness of transference in a markedly detached personality. Iriternational Jgurral of Psyhㅡ으브르노토, 1938, 19, 229-301.

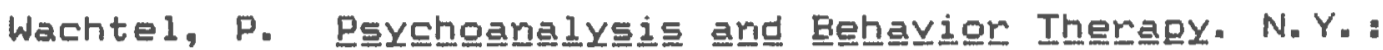
Basic Books, Inc., 1977.

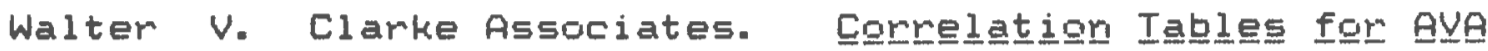
Patteern Uníversen, W.V. Clamke Associates, 1958.

Wiggins, J.S. Circumplex models of interpersonal behavior in clinical psychology. In P.C. Kendall and J.N. Butcher, (eds.). Haridbogok of Resegarch Methogds ir

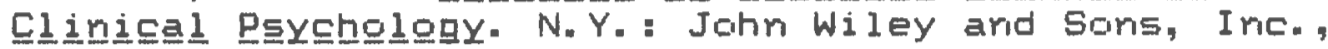
1982 .

Zetzell, E.R. Therapeutic alliance in the aralysis of hysteria (1958). In Cagacitity of Emgtional Growth. N. Y.: Intemational Universities Press, 1970. 